\title{
¿Variability and Mixing of the Filchner Overflow Plume on the Continental Slope, Weddell Sea
}

\author{
K. DAAE, I. FER, AND E. DARELIUS \\ Geophysical Institute, University of Bergen, and Bjerknes Centre for Climate Research, Bergen, Norway
}

(Manuscript received 9 May 2018, in final form 8 September 2018)

\begin{abstract}
A large fraction of Antarctic Bottom Water is produced in the Weddell Sea, through mixing between the cold and dense shelf water masses and the warm and saline off-shelf water. We present observations of the dense Filchner overflow plume from one mooring at the Filchner sill and two moorings located downstream, on the continental slope. The plume variability over the continental slope at a monthly time scale is related to upstream conditions at the Filchner sill, with a high correlation in density. Revised column-integrated volume transport calculations across the Filchner sill indicate 50\% higher values in 2010 compared with the earlier estimates available from 1985. Over the continental slope, the plume thickness fluctuates strongly between less than $25 \mathrm{~m}$ and more than $250 \mathrm{~m}$. Observations of elevated temperature variance and high Froude numbers at the plume interface imply high mixing rates and entrainment of ambient water masses. The mixing events typically coincide with shear spikes across the plume. The shear spikes appear quasi-periodically, when counterrotating oscillations with periods of 24 and $72 \mathrm{~h}$ align. The clockwise 24 -h oscillation is related to diurnal, barotropic tidal currents and topographic vorticity waves, whereas the counterclockwise 72-h oscillation is related to vortex stretching or topographic vorticity waves.
\end{abstract}

\section{Introduction}

Antarctic Bottom Water (AABW) contributes to the lower limb of the global ocean thermohaline overturning circulation (Orsi 1999). Recent studies indicate that AABW has freshened during the past 30 years, substantially affecting global sea level rise (Purkey and Johnson 2013; Jullion et al. 2013). A better understanding of the mechanisms changing the AABW properties could therefore lead to improved predictions of the rise in global sea level.

Approximately $40 \%-50 \%$ of the AABW originates from the Weddell Sea region (Fig. 1; Jacobs 2004; Ohshima et al. 2013), through a chain of processes occurring over the continental shelf, beneath the FilchnerRonne Ice Shelf (FRIS) and along the continental slope (Foldvik and Gammelsrød 1988). Over the continental shelf, cold and saline High Salinity Shelf Water (HSSW) is formed through atmospheric cooling and brine rejection from sea ice formation (Nicholls et al. 2009). HSSW penetrates deep into the FRIS cavity, interacts

¿ Denotes content that is immediately available upon publication as open access.

Corresponding author: K. Daae, kjersti.daae@uib.no with the ice shelf base (melting and mixing), and forms Ice Shelf Water (ISW; $\Theta<-1.9^{\circ}$; Gammelsrød et al. 1994). The ISW flows northward along the eastern flank of the Filchner Trough (FT), overflows the Filchner sill, and descends the continental slope as a dense plume (Foldvik et al. 2004, hereafter F04; Darelius et al. 2014a). This study focuses on processes controlling the variability and mixing of the Filchner overflow plume, and their implications for the production of AABW.

The Filchner overflow plume veers westward along the continental slope under the effect of rotation. A hydrographic transect collected across the continental slope in 1999 illustrates the bottom-attached plume (Fig. 2). The location of the transect is indicated in Fig. 1 (red line) and was originally presented by F04. In this snapshot, the plume is roughly $45 \mathrm{~km}$ wide and up to $500 \mathrm{~m}$ thick, and flows westward along the continental slope. A 500-m-thick layer of Warm Deep Water (WDW) is located between the cold surface water and the plume. The WDW is a cooler and fresher derivative of Circumpolar Deep Water (Heywood et al. 1998). In addition to the westward-flowing

This article is licensed under a Creative Commons Attribution 4.0 license (http://creativecommons.org/ licenses/by/4.0/) 


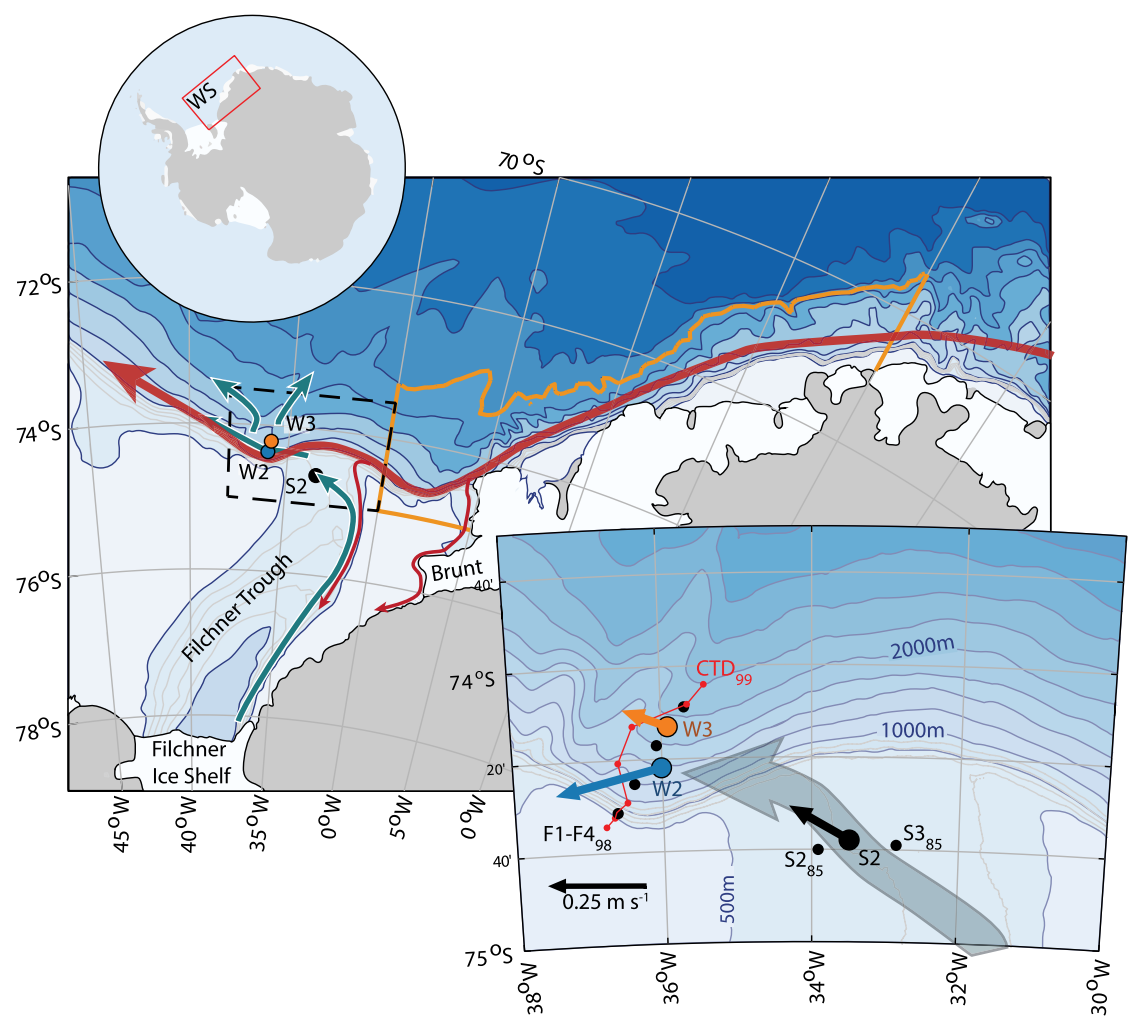

FIG. 1. Map showing the southern Weddell Sea (WS) bathymetry, circulation, and the mooring locations. The slope current is indicated by a thick red arrow, where the thinner arrows show the Antarctic Coastal Current and the seasonal inflow into the FT. The turquoise arrows show the overflow of ISW from the FT and possible pathways identified by F04. ERA upstream wind is extracted from the region bounded by the orange line and the coast. The lower inset shows a zoom-in of the region bounded by black dashed lines. Colored arrows from each mooring location show vector mean currents at $25 \mathrm{mab}$, with a corresponding scale arrow in the lower-left corner. Black dots refer to mooring locations in F04, and the red line indicates a conductivitytemperature-depth (CTD) transect obtained in 1999 during the cruise ANT XVI/2.

plume, two branches are topographically steered northward and downslope, along ridges that cross-cut the continental slope near $36^{\circ}$ and $37^{\circ} \mathrm{W}$ (F04; Darelius and Wåhlin 2007).

The Filchner overflow plume descends into the deep Weddell Sea. En route, the plume entrains ambient water masses and forms Weddell Sea Bottom Water (WSBW), which, through mixing with WDW, is ultimately transformed into AABW (Carmack and Foster 1977). The production rates of WSBW depend on the degree of mixing along the plume's pathway. F04 estimated an ISW flux of $1.6 \pm 0.5 \mathrm{~Sv}\left(1 \mathrm{~Sv} \equiv 10^{6} \mathrm{~m}^{3} \mathrm{~s}^{-1}\right)$ over the Filchner sill. Based on an estimated mixing and WDW entrainment factor of 2.7, F04 obtained a WSBW production of $4.3 \pm 1.4 \mathrm{~Sv}$ from the Filchner region.

Several processes contribute to the variability of the Filchner overflow. A seasonal signal is observed in the hydrographic properties of the ISW at the sill, but not in the overflow velocity (Darelius et al. 2014b). On monthly time scales, the overflow velocity is influenced by atmospheric forcing (Daae et al. 2018). In years with strong wind stress along the continental slope, the Filchner overflow velocity is positively correlated with the alongslope (toward $245^{\circ}$ ) wind stress upstream of the FT (area marked by orange lines in Fig. 1).

On shorter time scales (from $12 \mathrm{~h}$ to 1 week), internal tides and topographic vorticity waves (TVWs) along the continental slope contribute to enhanced subinertial energy and mixing. The upper continental slope is favorable for the generation of semidiurnal internal waves and is roughly collocated with the critical latitude for the semidiurnal internal tidal waves for $\mathrm{M}_{2}$, leading to high mixing rates (Daae et al. 2009; Fer et al. 2016). TVWs, also known as coastal trapped waves, are waves trapped by a coastal wall or a sloping topography to conserve potential vorticity (Rhines 1970; Mysak 1980; Brink 1991). In the Weddell Sea, excitation of barotropic TVWs at the diurnal frequency leads to energetic variability and, 


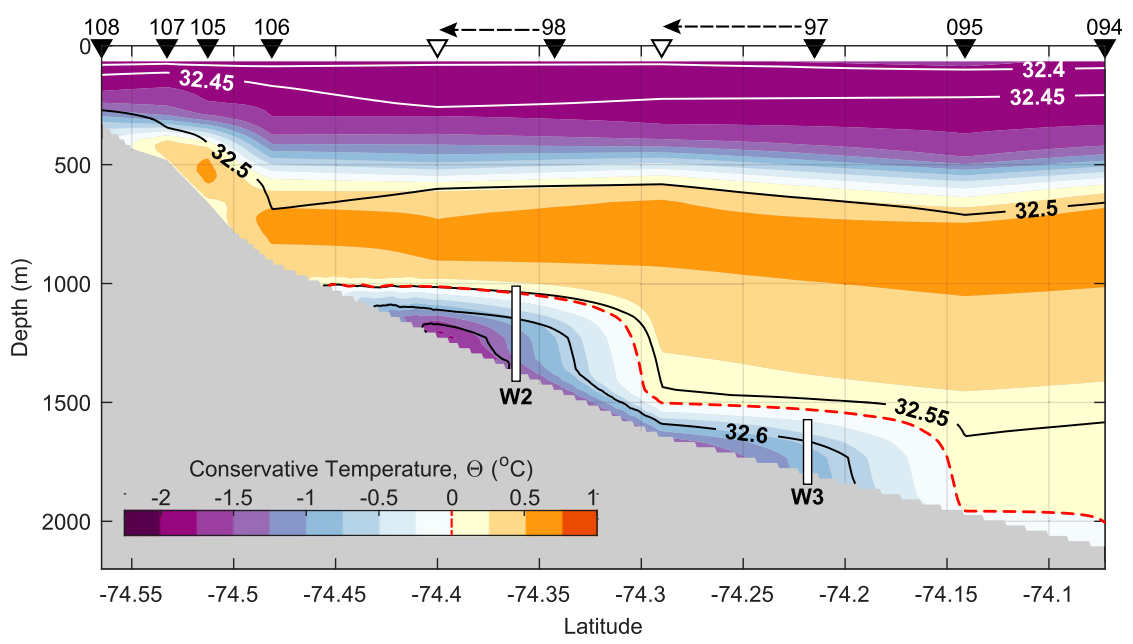

FIG. 2. Conservative Temperature $\Theta$ (colors) and density anomalies $\sigma_{1}$ (contours) across the continental slope, obtained from cruise ANT XVI/2 in 1999 (Fahrbach and el Naggar 2001). The red dashed line indicates the $0^{\circ} \mathrm{C}$ isotherm defined here as the upper threshold temperature for the plume. The transect was originally presented in F04. Here, the temperature is converted to $\Theta$, and the horizontal axis represents latitude instead of distance. The section (shown in red on the map in Fig. 1) is obtained roughly along a northeast-oriented ridge. However, two profiles (stations 97-98) are obtained closer to the ridge, where the isobaths curve toward northwest. To account for the shallower isobaths at these stations, compared to the isobaths along a straight section line, we have shifted their latitudinal position. Station numbers and the real latitudes are shown with black annotated triangles. The shifted latitudes of stations 97-98 are shown with white triangles. The W2 and W3 moorings are overlain in this snapshot of observations for context.

possibly, mixing at the diurnal frequency (Middleton et al. 1987; Foldvik et al. 1990; Semper and Darelius 2017). Energetic, lower-frequency (subinertial) oscillations are also observed over the continental slope (Darelius et al. 2009; Jensen et al. 2013). The properties of these oscillations, with periods of $35 \mathrm{~h}, 72 \mathrm{~h}$, and 6 days, are consistent with westward-propagating TVWs (Jensen et al. 2013). Based on numerical simulations, Marques et al. (2014) show that dense overflows, such as the Filchner overflow plume, may generate TVWs with properties consistent with the observed oscillations. Oscillations with comparable frequencies are also observed in other overflows, for example, the Denmark Strait overflow (Smith 1976) and the Faroe Bank Channel overflow, affecting vertical entrainment (Darelius et al. 2013) and horizontal stirring rates (Voet and Quadfasel 2010).

In this study, we investigate the characteristics and variability of the Filchner overflow plume from daily to monthly time scales, with a focus on shorter time scales and mixing processes. We present new datasets of hydrography and currents from two moorings (W2 and W3) located on the continental slope, approximately $80 \mathrm{~km}$ downstream of the Filchner sill, and revisit earlier published data from one mooring located at the sill (S2; Fig. 1). The datasets over the continental slope have a high temporal and vertical resolution, revealing strong high-frequency variability of the Filchner overflow plume, which has not been observed previously. While the monthly scale variability at the Filchner sill and over the continental slope is related, the shorter-term variability over the upper slope is associated with energetic subinertial oscillations with periods of 24 and $72 \mathrm{~h}$. Energetic plume events with threefold increase in plume thickness occur on 1-3-day time scales. During the events, shear spiking and mixing align in time with counterrotating subinertial oscillations and reveal plume dynamics more complex than previously thought.

\section{Data and methods}

\section{a. Atmospheric data}

Atmospheric data are obtained from the ERA-Interim reanalysis dataset with $0.75^{\circ}$ horizontal resolution (hereinafter ERA; Dee et al. 2011). We extract ERA wind velocity at $10 \mathrm{~m}$ above sea level and sea ice concentration over the continental slope upstream of the FT, and bounded by the $3500-\mathrm{m}$ isobath (indicated by an orange line in Fig. 1). Wind stress is calculated following the procedure of Andreas et al. (2010), where the drag coefficient is a function of the sea ice concentration. The coordinate system for wind stress is rotated, with the along-flow component directed toward $245^{\circ}$, roughly along the continental slope. 


\section{b. Moored instruments}

Yearlong datasets of current, temperature, and conductivity from three locations at the continental shelf and slope of the southern Weddell Sea are collected using moored instrument arrays. The moorings were deployed in February 2010 and recovered in February 2011. One mooring (S2) was deployed on the Filchner sill at $602 \mathrm{~m}$ depth. Two moorings, W2 and $\mathrm{W} 3$, were deployed on the steep continental slope $(\alpha=$ $0.03)$ at the 1411- and 1844-m isobaths. W2 and W3 are separated by $16 \mathrm{~km}$ and are located along the ISW pathway, roughly $80 \mathrm{~km}$ downstream of $\mathrm{S} 2$, and in the vicinity of the F-mooring array from 1998 (Fig. 1; F04).

The moorings were equipped with Sea-Bird Electronics temperature (SBE39) and conductivity and temperature recorders (SBE37 Microcat), single-point current meters (Aanderaa recording current meter RCM-7/8/Seaguard), and acoustic Doppler current profilers [ADCPs; Teledyne RD Instruments (RDI) $300-\mathrm{kHz}$ Sentinel and $75-\mathrm{kHz}$ Longranger]. The details of the moorings are given in Table 1 . The RCMs averaged 50 evenly distributed samples per hour. The RDI ADCPs sampled an ensemble of 30 pings collected in burst mode for the first $60 \mathrm{~s}$ every $20 \mathrm{~min}$. The data return from the current profilers varies, and we exclude data from depth bins where the data return is below $80 \%$. The current profilers depleted batteries in December 2010. One of the RCM-7s [W2 at $84 \mathrm{~m}$ above bottom (mab)] has a gap in the data series between 16 June and 11 August 2010. The moorings were sufficiently taut, with maximum drawdowns of 7, 12, and $22 \mathrm{~m}$ at $\mathrm{W} 2, \mathrm{~W} 3$, and $\mathrm{S} 2$, respectively.

We calculate Absolute Salinity $\left(S_{\mathrm{A}}\right)$, Conservative Temperature $(\Theta)$, and potential density anomalies referenced to $1000 \mathrm{dbar}\left(\sigma_{1}\right)$ according to the International Thermodynamic Equation of Seawater-2010 (TEOS10; IOC/SCOR/IAPSO 2010). The observations cover the 600-1800-m depth range, hence $\sigma_{1}$ is the relevant density. The salinity time series are corrected for sensor drift. In addition, we utilized the narrow range in ISW temperature and salinity properties to correct the salinity records at $28 \mathrm{mab}$ at W2 and at $70 \mathrm{mab}$ at W3 with a small offset of +0.012 and $-0.013 \mathrm{~g} \mathrm{~kg}^{-1}$, respectively, based on the ISW properties at adjacent instruments.

\section{c. Transport density $T_{d}$}

Transport estimates of the Filchner overflow plume are sensitive to the threshold values defining the cold water and to the vertical and lateral integration of velocity. The presented dataset is limited to one mooring over the Filchner sill and two moorings across the continental slope. To avoid the large uncertainty on the width of the plume at each mooring, we report column-integrated transports, also referred to as transport density $T_{d}$.

Transport density $T_{d}$ is calculated using the along-flow component (following the main current direction) observed at $25 \mathrm{mab}\left(299^{\circ}\right.$ at $\mathrm{S} 2,256^{\circ}$ at W2, and $291^{\circ}$ at W3), by vertical integration up to the plume interface. The current and hydrography profiles are interpolated to common 5-m vertical bins. Near the bottom, the current velocity is extrapolated from the lowermost current meter $(25 \mathrm{mab})$. The effect of bottom friction in $T_{d}$ is accounted for by subtracting $\delta_{E} U / 2$, where the bottom Ekman layer thickness $\delta_{E}$ is set to $10 \mathrm{~m}$, and $U$ is the along-flow current component near the bottom. The height of the plume interface (i.e., the plume thickness $\left.H_{p}\right)$ is detected using different criteria at the Filchner sill (S2) and over the slope (W2 and W3). ISW is the dominating water mass at $\mathrm{S} 2$. Diagrams of $\Theta-S_{\mathrm{A}}$ (Fig. 3a) show that ISW typically has $\sigma_{1}>32.55 \mathrm{~kg} \mathrm{~m}^{-3}$, which we use as a threshold for the dense plume at S2. At W2 and W3, there is a strong temperature gradient across the plume interface. We define the Filchner overflow plume as water with $\Theta<0^{\circ} \mathrm{C}$, which is commonly used to define AABW (Foster and Carmack 1976). The plume thickness $H_{p}$ is defined as the height above bottom of the $0^{\circ} \mathrm{C}$ isotherm.

There is a 56-day gap in the point current meter time series from 84 mab at W2 (section $2 b$ ). High vertical correlation $(R \sim 0.7)$ between the point current meter at $84 \mathrm{mab}$ and the current data below (25 mab) and above (198 mab) enables us to fill this gap using multiple regression to predict the current velocity at 84 mab.

The near-bottom current meters at $\mathrm{W} 2$ and $\mathrm{W} 3$ recorded throughout the analysis period, whereas the current profilers stopped recording in December 2010. The overflow plume is bottom intensified, and the near-bottom measurements are representative of the transport variability. The variability from plume thickness is relatively accurately captured from the complete temperature records. To obtain crude transport density estimates for the remaining record (after 10 December), we rely on the point current meters near the bottom and fill the gaps higher in the water column using the time-averaged current profiles from the period when the profilers were operational. Thus, after 10 December 2010, the variability captured in the $T_{d}$ time series is a combination of that from the bottom current and the variability in the layer thickness, and the transport estimate must be interpreted with caution.

\section{d. Filtering analysis}

Most figures and calculations are based on hourlyaveraged data. In addition, we study variability at different time scales using low-pass and high-pass filters. Where a filter is applied, the cutoff period is indicated. Low-pass filters are calculated using phase-preserving moving-averaging 
TABLE 1. Overview of the moorings on the Filchner sill (S2) and over the continental slope downstream (W2 and W3). Parameter $T$ is temperature, $C$ is conductivity, $P$ is pressure, $V$ is horizontal velocity, and $W$ is vertical velocity. In the height column, three numbers separated by colons indicate a series of depth bins, where the first number is the deepest bin, the last number is the shallowest bin, and the middle number is the vertical distance between bins.

\begin{tabular}{|c|c|c|c|c|c|c|c|c|}
\hline $\begin{array}{l}\text { Mooring } \\
\text { name }\end{array}$ & $\begin{array}{l}\text { Time } \\
\text { (in, out) }\end{array}$ & $\begin{array}{l}\text { Position } \\
\text { (lon, lat) }\end{array}$ & $\begin{array}{l}\text { Record } \\
\text { days }\end{array}$ & $\begin{array}{c}\text { Bottom } \\
\text { depth }(m)\end{array}$ & $\begin{array}{l}\text { Height } \\
(\mathrm{mab})\end{array}$ & Parameter & Instrument & $\begin{array}{l}\text { Sampling } \\
\text { rate (min) }\end{array}$ \\
\hline \multirow[t]{6}{*}{ S2 } & $\begin{array}{l}1613 \text { UTC } 13 \text { Feb } 2010, \\
1643 \text { UTC } 11 \text { Feb } 2011\end{array}$ & $\begin{array}{c}33^{\circ} 30^{\prime} 10^{\prime \prime} \mathrm{W} \\
74^{\circ} 38^{\prime} 3^{\prime \prime} \mathrm{S}\end{array}$ & 362 & 612 & 25 & $T, V$ & RCM-7 & 60 \\
\hline & & & 362 & & 26 & $T, C, P$ & Microcat & 5 \\
\hline & & & 362 & & 104 & $T, V$ & RCM-7 & 60 \\
\hline & & & 362 & & 105 & $T, C$ & Microcat & 5 \\
\hline & & & 362 & & 176 & $T, V$ & RCM-7 & 60 \\
\hline & & & 362 & & 177 & $T, C, P$ & Microcat & 5 \\
\hline \multirow[t]{12}{*}{ W2 } & $\begin{array}{l}2100 \text { UTC } 17 \text { Feb } 2010 \\
0806 \text { UTC } 14 \text { Feb } 2011\end{array}$ & $\begin{array}{l}36^{\circ} 1^{\prime} 13^{\prime \prime} \mathrm{W} \\
74^{\circ} 21^{\prime} 41^{\prime \prime} \mathrm{S}\end{array}$ & 362 & 1411 & 25 & $T, V$ & RCM-7 & 60 \\
\hline & & & 362 & & 28 & $T, C$ & Microcat & 5 \\
\hline & & & 362 & & 50 & $T, C, P$ & Microcat & 5 \\
\hline & & & 362 & & 63 & $T, P$ & SBE39 & 5 \\
\hline & & & $274^{\mathrm{a}}$ & & 84 & $T, V$ & RCM-7 & 60 \\
\hline & & & 362 & & 94 & $T, C, P$ & Microcat & 5 \\
\hline & & & 362 & & 138 & $T$ & SBE39 & 5 \\
\hline & & & 362 & & 181 & $T, C, P$ & Microcat & 5 \\
\hline & & & $299-303^{b}$ & & $198: 4: 234$ & $T, V, W$ & RDI Sentinel down & 20 \\
\hline & & & 362 & & 257 & $T, C$ & Microcat & 5 \\
\hline & & & 362 & & 287 & $T, C, P$ & Microcat & 5 \\
\hline & & & 319 & & $296: 4: 396$ & $T, V, W$ & RDI Longranger up & 20 \\
\hline \multirow[t]{10}{*}{ W3 } & $\begin{array}{l}1300 \text { UTC } 16 \text { Feb } 2010, \\
1250 \text { UTC } 14 \text { Feb } 2011\end{array}$ & $\begin{array}{c}35^{\circ} 55^{\prime} 18^{\prime \prime} \mathrm{W} \\
74^{\circ} 13^{\prime} 6^{\prime \prime} \mathrm{S}\end{array}$ & 360 & 1844 & 25 & $T, P, V$ & Seaguard & 20 \\
\hline & & & 360 & & 28 & $T, C$ & Microcat & 5 \\
\hline & & & 360 & & 70 & $T, C, P$ & Microcat & 5 \\
\hline & & & 360 & & 82 & $T$ & SBE39 & 5 \\
\hline & & & 360 & & 93 & $V$ & RCM-8 & 60 \\
\hline & & & 360 & & 109 & $T, C, P$ & Microcat & 5 \\
\hline & & & 360 & & 160 & $T, C$ & Microcat & 5 \\
\hline & & & 360 & & 190 & $T, C, P$ & Microcat & 5 \\
\hline & & & $262-304^{\mathrm{b}}$ & & $223.5: 4: 271.5$ & $T, V, W$ & RDI Sentinel down & 20 \\
\hline & & & 360 & & 277 & $T, C, P$ & Microcat & 5 \\
\hline
\end{tabular}

${ }^{\mathrm{a}}$ Missing data between 16 Jun and 11 Aug 2010.

${ }^{\mathrm{b}}$ Shorter time series at the deepest cells.

with Hanning windows. The monthly scale variability is studied using a 15-day low-pass filter, which removes the high-frequency variability such as tides, TVWs, and shortduration storm events. Shorter filters of 13 or $24 \mathrm{~h}$ are used to smooth the time series and exclude the semidiurnal to diurnal tidal signal. High-frequency temperature anomalies associated with the plume interface at $\mathrm{W} 2$ and $\mathrm{W} 3$ are obtained from 5-min temperature records, high-pass filtered at 1 -h cutoff frequency.

\section{e. Bulk shear $S_{b}$}

The bulk shear at W2 is calculated from $S_{b}=\Delta \mathbf{U} / H$, where $\Delta \mathbf{U}$ is the velocity difference between the upper and lower layer, and $H$ is the vertical distance between the layers, set to $H=361 \mathrm{~m}$. The lower-layer velocity is represented by the velocity at $25 \mathrm{mab}$, and the upper-layer velocity is calculated from the vertically averaged current between 376 and 396 mab, that is, generally well above the plume. We remove semidiurnal tidal signals using a 13-h low-pass filter prior to calculation of $S_{b}$.

\section{f. Internal Froude number Fr}

The internal Froude number $\left(\mathrm{Fr}=\Delta \mathbf{U} / \sqrt{g^{\prime} H_{p}}\right)$, compares the current speed and the phase speed of a long interfacial gravity wave in a two-layer system. Here, $\Delta \mathbf{U}$ is the velocity difference between the two layers, $H_{p}$ is the thickness of the lower layer (i.e., the plume thickness), and $g^{\prime}=g \Delta \rho / \rho_{p}$ is the reduced gravity in a two-layer system, where $g$ is the gravitational constant, $\Delta \rho$ is the density difference between the two layers, and $\rho_{p}$ is the lower layer (i.e., plume) density. Fr is equivalent to the inverse square root of the commonly used interfacial (or bulk) 


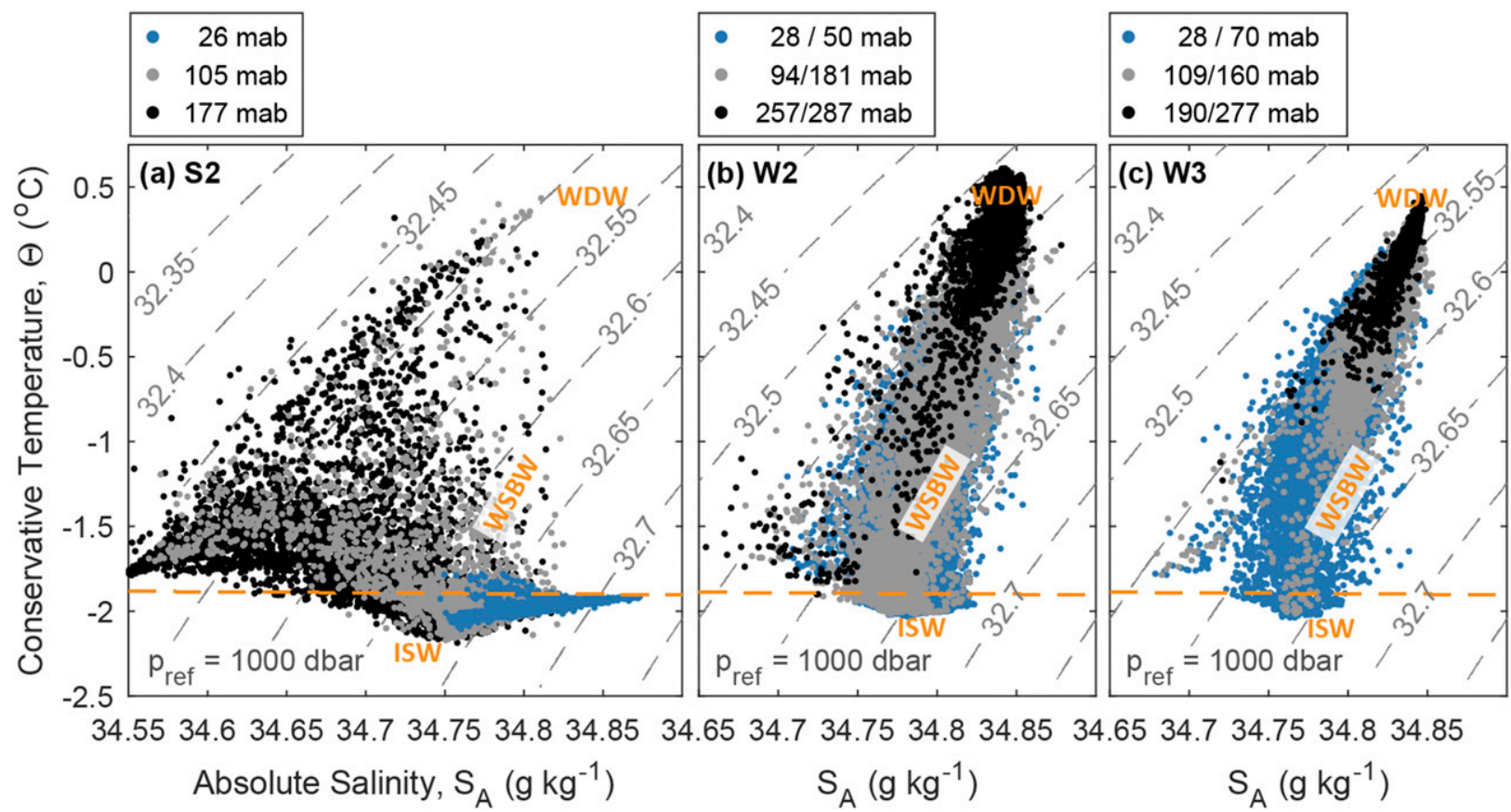

FIG. 3. Diagrams of $\Theta-S_{\mathrm{A}}$ for (a) S2, (b) W2, and (c) W3. Contours of density anomalies are referenced to 1000 dbar $\sigma_{1}$. The orange dashed lines indicate the freezing temperature of seawater at the surface.

Richardson number (Ri; Turner 1986), representing the relative importance of buoyancy and inertial forces. Increasing velocity difference $(\Delta \mathbf{U})$ between the dense plume and the overlying water leads to high Froude numbers and low Ri, causing shear instability at the upper interface of the overflow and resulting in mixing and entrainment between the plume and the ambient water masses (Turner 1986; Cenedese and Adduce 2008). When the ambient is homogeneous, entrainment and mixing is dominated by the engulfment of the external fluid by large-scale eddies. When the surrounding is stratified, buoyancy forces limit the perturbations vertically, but the interface contains small-scale shearing and wavelike motions. Turner (1986) describes the entrainment mechanism either as the recoil of the interface after it has been distorted by an impinging eddy, or as internal wave breaking.

Fr is calculated at $\mathrm{W} 2$ and $\mathrm{W} 3$, and $H_{p}$ is defined as the height of the $0^{\circ} \mathrm{C}$ isotherm. At W2, $\Delta \mathbf{U}$ is the same as for bulk shear. At W3, the upper-layer velocity is calculated from vertically averaged velocities between 252 and 272 mab, that is, above the plume, and the lower-layer velocity is represented by the point current meter at 25 mab. We estimate $\Delta \rho$ as the difference between $\sigma_{1}$ in the lower layer measured at $28 \mathrm{mab}\left(\rho_{p}\right)$, and a constant upper-layer density $\left(\sigma_{1}=32.52 \mathrm{~kg} \mathrm{~m}^{-3}\right.$ at $\mathrm{W} 2$, and $\sigma_{1}=$ $32.53 \mathrm{~kg} \mathrm{~m}^{-3}$ at W3), representative of the ambient water density at each mooring.

\section{Results}

In this section we present observations of the Filchner overflow plume at the Filchner sill and on the continental slope downstream. We start with the monthly scale variability at the three moorings and estimates of the Filchner overflow transports density $T_{d}$ (section 3a), then present shorter time series of the variability in plume thickness at W2 and W3 and describe thick-plume events (section $3 b$ ). Shear and mixing across the plume interface at $\mathrm{W} 2$ are presented in section $3 \mathrm{c}$. The implications of the results are discussed in section 4 .

\section{a. The Filchner overflow plume}

A thick layer of ISW ( $>100 \mathrm{~m})$ is observed at S2, at the Filchner sill (Fig. 4c). The overflow is directed toward $298^{\circ}$ and reaches the upper instrument level $(176 \mathrm{mab})$ $65 \%$ of the time. Intrusions of lighter water masses $\left(\sigma_{1}<\right.$ $32.5 \mathrm{~kg} \mathrm{~m}^{-3}$ ) are observed at 104 and 176 mab (Figs. 3, 4c). The intrusions are often accompanied by low transport values, which could indicate that the core of the ISW is deflected away from the S2 site by lighter water masses. The hydrographic properties of the ISW layer at S2 vary seasonally (Darelius et al. 2014b). Minimum temperatures are normally found in September-October, and maximum temperatures in April-May. In 2010, the seasonal signal is different at the upper (176 mab) and lower instruments (25 and $104 \mathrm{mab}$ ). While the seasonality at 176 mab agrees 


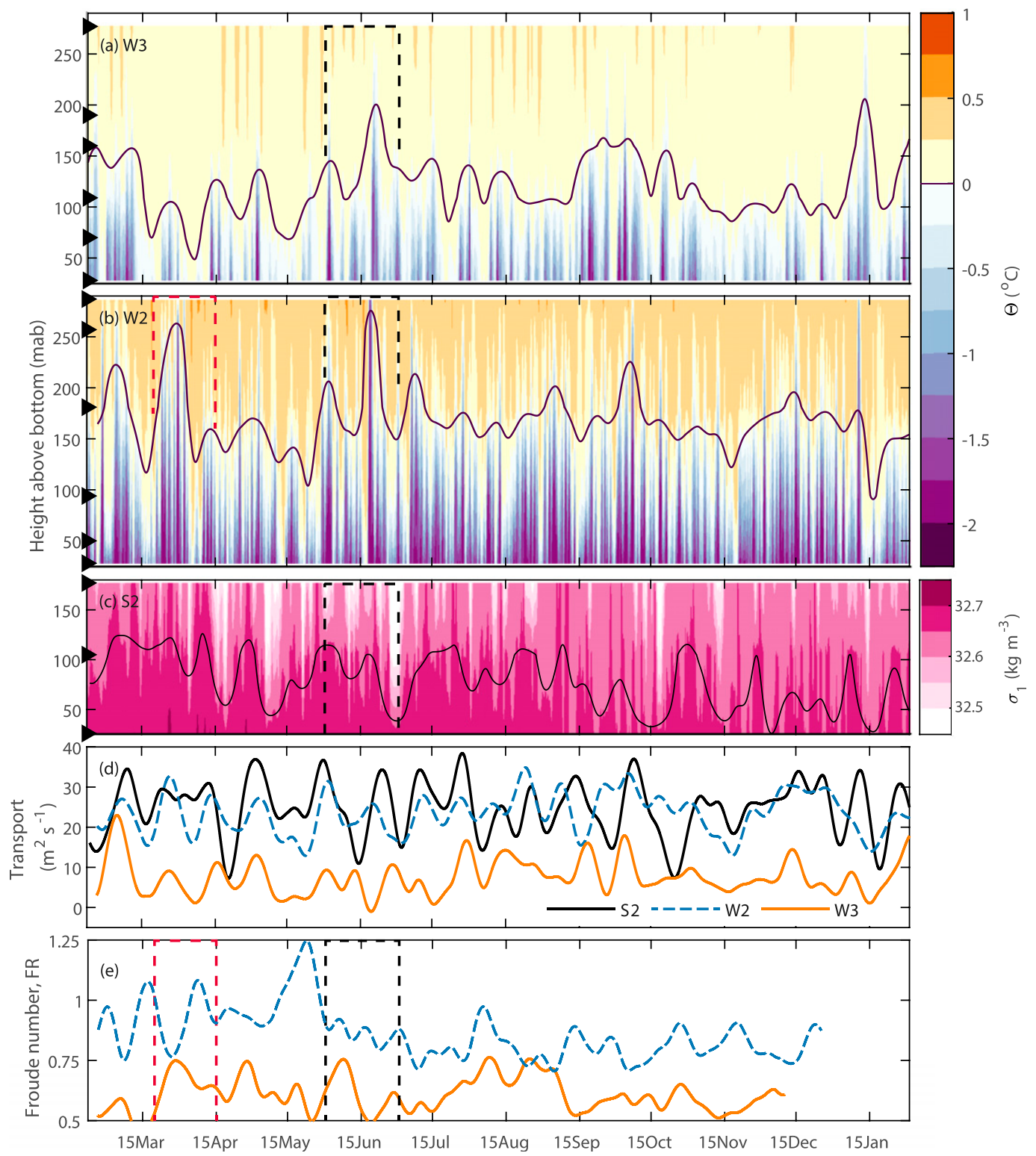

FIG. 4. The 24-h low-passed time series of $\Theta$ at (a) W3 and (b) W2, and (c) potential density anomaly referenced to $1000 \mathrm{dbar} \sigma_{1}$ at S2. Contours of the 15-day low-passed $\Theta=0^{\circ} \mathrm{C}$ isotherms at W2 and W3 (purple lines) and the $\sigma_{1}=32.65 \mathrm{~kg} \mathrm{~m}^{-3}$ isopycnal at S2 (black line) are drawn on top. Time series of 15-day low-passed (d) plume $T_{d}$ and (e) Fr at W2 (blue), W3 (orange), and S2 (black). The black dashed boxes indicate the period shown in Fig. 5, and the red dashed boxes indicate the period shown in Fig. 9.

with earlier observations, we observe continuous cooling and freshening near the bottom from July 2010 to the end of record in February 2011 (not shown). At low temperatures, salinity dominates the density. The densest ISW is observed near the bottom, in April-May, when $S_{\mathrm{A}}>$ $34.85 \mathrm{~g} \mathrm{~kg}^{-1}$. In the same period, warmer and lighter water masses are present higher in the water column, leading to maximum vertical density gradients.

The Filchner overflow plume is observed to flow along the continental slope at both W2 and W3 (Fig. 1). The mean temperature at $25 \mathrm{mab}$ at $\mathrm{W} 2(\mathrm{~W} 3)$ is $-1.35^{\circ} \mathrm{C}$ $\left(-0.65^{\circ} \mathrm{C}\right)$, and ISW is present $20 \%(3 \%)$ of the time. At both W2 and W3, we observe minimum bottom temperatures in September-October and maximum temperatures in April-May. The variations in bottom temperatures are consistent with earlier observations (F-moorings in 1998) from the same region (Darelius et al. 2014b) and could imply a seasonal signal.

WDW $\left(\Theta>0^{\circ} \mathrm{C}\right)$ is the dominant water mass in the upper layer. WSBW is present at all instrument levels, 
indicating mixing and entrainment of WDW into the Filchner overflow plume (F04). The mean plume thickness $H_{p}$ is $137 \mathrm{~m}$ at $\mathrm{W} 2$ and $100 \mathrm{~m}$ at $\mathrm{W} 3$, with standard deviations of $65 \mathrm{~m}$ at W2 and $49 \mathrm{~m}$ at W3. The plume reaches the upper instrument at W2 (287 mab) on several occasions (Fig. 4b).

F04 estimated the transport of cold water in roughly the same area as our moorings [from 1998 over the continental slope (F-moorings) and from 1985 across the Filchner sill; see the locations on the map in Fig. 1]. A comparison with our measurements is possible after converting their total volume transports to transport densities $T_{d}$, using the parameters in their Table 4. This is necessary because we have fewer moorings, and both the location and the vertical resolution are different. At F04's F2 and F3, located in the vicinity of W2 and W3, we obtain $T_{d}=27$ and $26 \mathrm{~m}^{2} \mathrm{~s}^{-1}$, respectively, slightly higher than our estimate of $T_{d}=23 \mathrm{~m}^{2} \mathrm{~s}^{-1}$ at W2. Over the deeper part of the continental slope, the transport density is weaker, with $T_{d}=8 \mathrm{~m}^{2} \mathrm{~s}^{-1}$ at W3 (1844-m isobath) and $T_{d}=1 \mathrm{~m}^{2} \mathrm{~s}^{-1}$ at F4 (1984-m isobath).

At the sill, $T_{d}=9 \mathrm{~m}^{2} \mathrm{~s}^{-2}$ at $\mathrm{S} 2$ and $T_{d}=15 \mathrm{~m}^{2} \mathrm{~s}^{-2}$ at S3 from 1985 (F04). These values are smaller than our estimate of $T_{d}=25 \mathrm{~m}^{2} \mathrm{~s}^{-2}$ at $\mathrm{S} 2$. The current velocity at 25 mab in 2010 is roughly twice that in $1985\left(0.17 \mathrm{~m} \mathrm{~s}^{-1}\right.$ compared with $0.08 \mathrm{~m} \mathrm{~s}^{-1}$ ). The location of S2 in our study is between the S2 and S3 positions in 1985, approximately $13 \mathrm{~km}$ east of the S2 location in 1985 . The difference in 1985 and 2010 could be caused by interannual variability, or from the location of the mooring relative to the core of the ISW, and is further discussed in section $4 \mathrm{~d}$.

The instrumentation and measurement depths at S2 are similar in 1985 and 2010. A calculation using the method described by F04 to extrapolate in the vertical and to define the plume height yields $T_{d}=34 \mathrm{~m}^{2} \mathrm{~s}^{-2}$ at S2 in 2010 , approximately $50 \%$ larger than our estimate based on interpolated currents as described in section $2 \mathrm{c}$.

The monthly scale plume variability at $\mathrm{W} 2$ is connected to the upstream variability at $\mathrm{S} 2$. There is a strong correlation between $T_{d}$ at S2 and W2 (Fig. 4d). We compute normalized correlation coefficients following Sciremammano (1979), and denote significance levels by superscripts (i.e., $R=0.6^{99}$ means that $R$ is above the $99 \%$ significance level). The correlation between $T_{d}$ at $\mathrm{S} 2$ and $\mathrm{W} 2$ is $R=0.30^{95}$. The relation is stronger in March to July $\left(R=0.49^{95}\right)$, when the along-flow bottom currents are highly correlated (not shown). The highest correlation between S2 and W2 is found for density, with $R=0.63^{99}$ between W2 (25 mab) and S2 (177 mab), with a lag of 4.75 days. This lag is consistent with the advection time scale of 5.5 days, estimated from the mean overflow velocity at $\mathrm{S} 2$, and a distance of $80 \mathrm{~km}$.
The monthly scale correlation in density between W2 and W3 is high $\left(R=0.62^{99}\right.$ at zero lag), but the correlation between $\mathrm{W} 3$ and $\mathrm{S} 2$ is weaker $\left(R=0.33^{90}\right.$ at 5.5 days lag). W3 is located roughly $16 \mathrm{~km}$ downslope from W2, and not strictly downstream of W2. At both locations, the mean plume velocities are directed along the continental slope (section 3a). Figure 2 shows a snapshot of the Filchner overflow plume, where the plume is wide enough to cover both W2 and W3 simultaneously. The covariability between W2 and W3 could hence be a result of similar plume characteristics and plume variability across the plume width.

\section{b. Thick-plume events}

At W2, the plume thickness fluctuates between less than $25 \mathrm{~m}$ (height above bottom of the deepest instrument) and more than $287 \mathrm{~m}$ (height above bottom of the uppermost instrument at W2) over typical time scales of 1-3 days. We detect 240 events when the plume thickness exceeds $100 \mathrm{~m}$ during the 362-day record, yielding an average time interval of $\sim 36 \mathrm{~h}$ between subsequent thick-plume events. Figure 5 shows details of hydrography and currents in June, when strong variations in the plume thickness are observed at all three moorings. The thickest plume event at W2 occurs on 18-19 June, with a minimum temperature of $\Theta=-1.79^{\circ} \mathrm{C}$ at 287 . A similar cold event occurs 2 days later at $\mathrm{W} 3$, with minimum temperature $\Theta=-1.23^{\circ} \mathrm{C}$ at 190 mab (Figs. 5a,b). Elevated temperature variance is associated with the passage of thick-plume events, as seen in the high-passed records from multiple levels (Fig. 5, red lines), and is suggestive of rapid mixing with the ambient (Cenedese and Adduce 2008). Just before, and early into the thick-plume events, Froude numbers exceed unity (Figs. 5d, 9), which indicates entrainment and mixing with the surrounding waters (Turner 1986).

Ensembles of plume events are extracted from the dataset as 48-h segments, centered at the time of maximum $H_{p}$. Ensembles of the thickest plume events at W2 $\left(H_{p}>250 \mathrm{~m}\right)$ and $\mathrm{W} 3\left(H_{p}>160 \mathrm{~m}\right)$, constructed from 20 and 22 events, are shown in Fig. 6, together with the percentage of the ensemble members with high temperature variance, high Froude numbers, and large bulk-shear-squared temporal gradients. At both sites, the average plume event is skewed. The coldest and densest water near the bottom appears before the time of maximum plume thickness. The plume characteristics are more pronounced at W2 compared with W3. At W3, current vectors rotate during some distinct thick-plume events (e.g., 2 June), but this is not a general feature. 

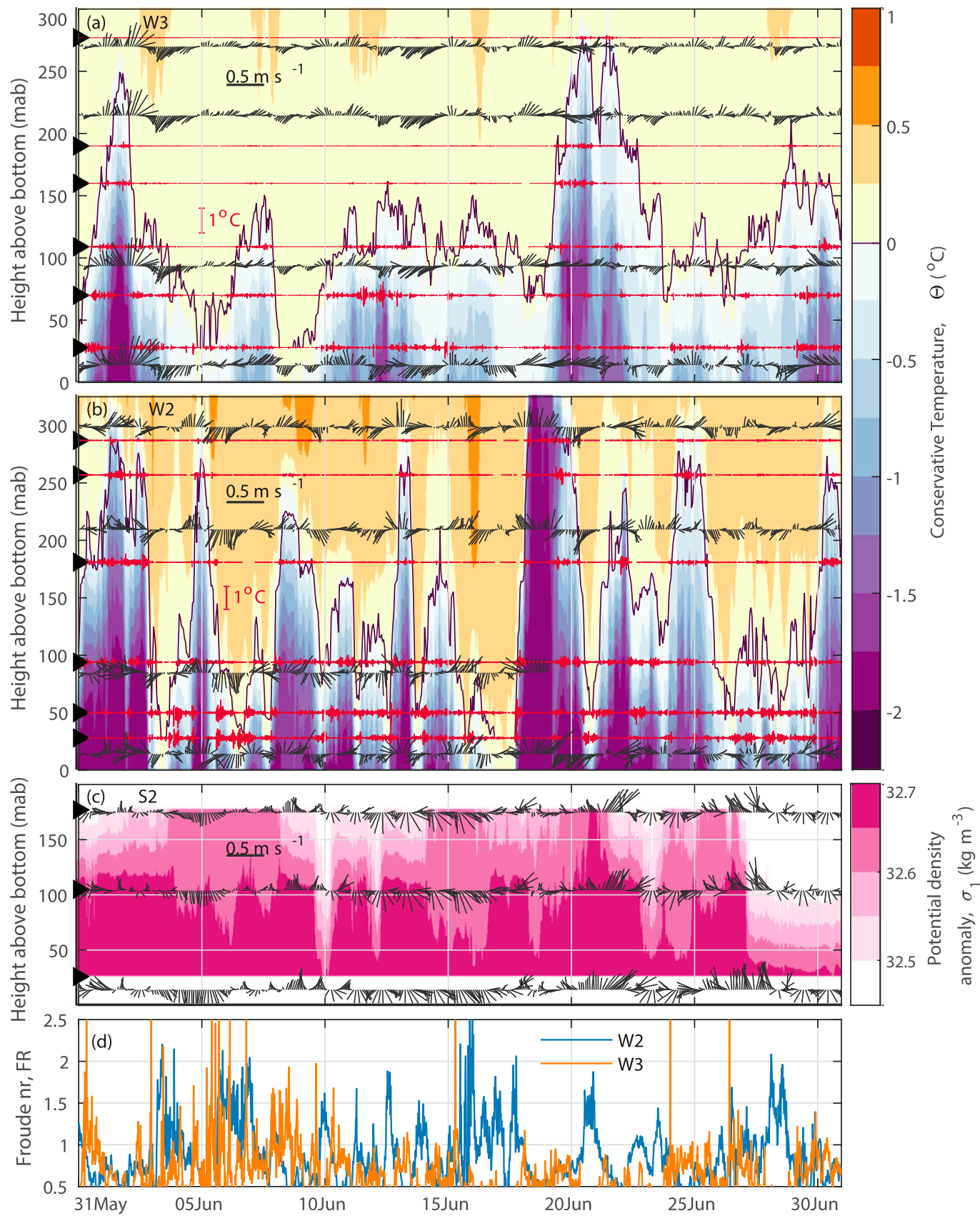

FIG. 5. Time series of hourly averaged $\Theta$ at (a) W3 and (b) W2, and (c) potential density anomaly referenced to $1000 \mathrm{dbar} \sigma_{1}$ at S2. Vectors of current anomalies (black) are shown from selected depths, with scales indicated by black horizontal bars. High-passed temperature anomalies at W3 and W2 are shown in red, with scales indicated by red vertical bars. (d) Time series of Fr, calculated from the along-flow component of the current velocity at W2 (blue) and W3 (orange).

At W2, the plume extends higher up in the water column, the plume interface is steeper, there is a vertical shear between the plume and the upper layer, and more ensemble members have high Froude numbers and temperature variances during the early and late stages of the thick-plume events (Fig. 6e). W2 velocity anomalies tend to rotate clockwise from westward to eastward, directed downslope during periods of maximum plume thickness (black vectors in Figs. 5b, 6). The same pattern, that is, high mixing rates before and after a plume thickness maximum and downslope flow during thickplume events, was observed in the oscillations of the 

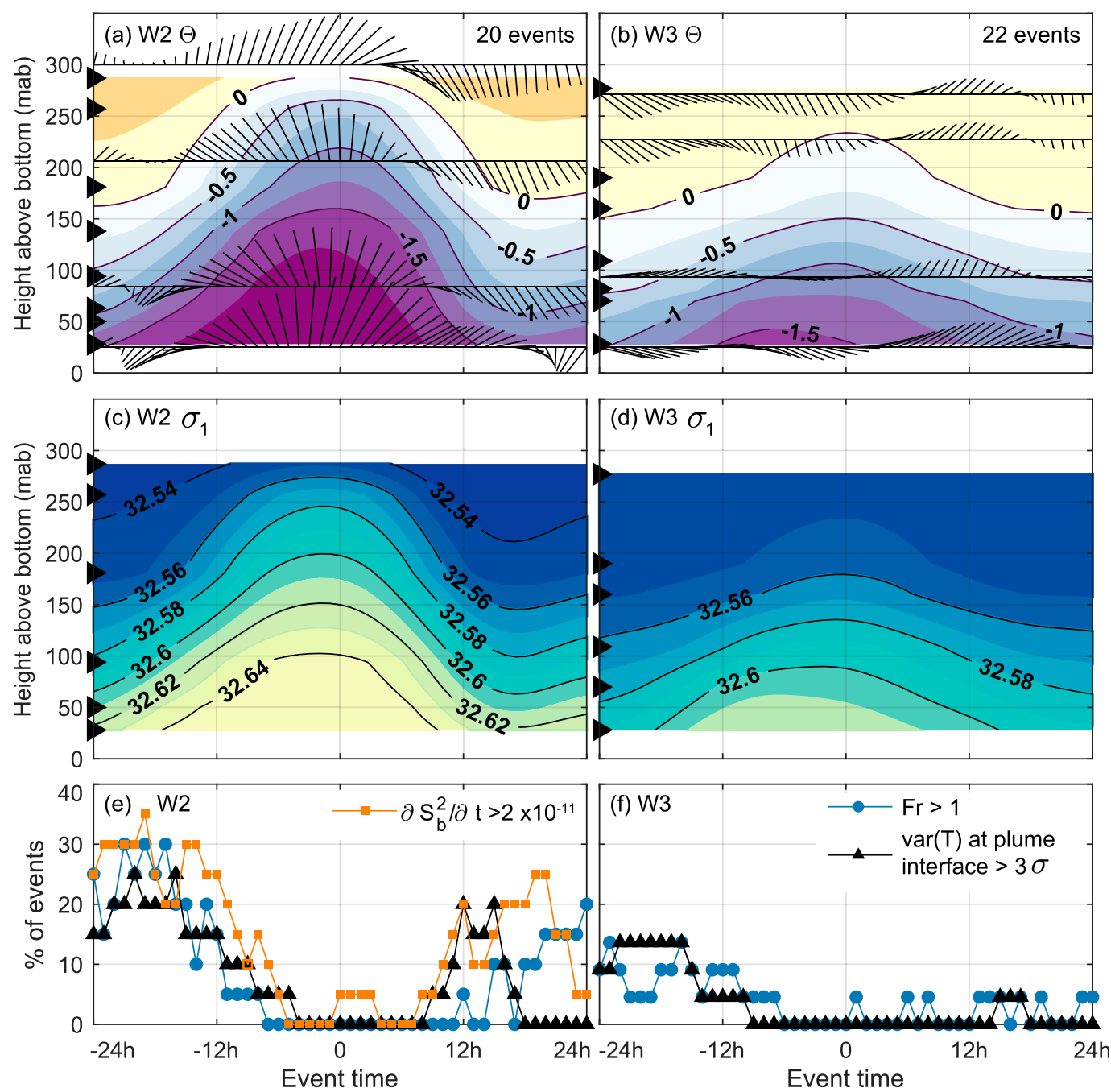

FIG. 6. Ensembles of (a),(b) $\Theta$, (c),(d) $\sigma_{1}$, and (e),(f) percent of events with high Fr (blue) and high temperature variance (black) during thick-plume events at (left) W2 $(H>250 \mathrm{~m})$ and (right) W3 $(H>160 \mathrm{~m})$. Current velocities, $\Theta$, and $\sigma_{1}$ are low-pass filtered with a cutoff at $13 \mathrm{~h}$, and the temperature variance is calculated over 6-h moving windows. The black lines in (e) and (f) indicate the percentage of the events where the temperature variance is larger than three standard deviations, estimated from all the events included in the ensembles. In (e), the orange lines denote percent of events with bulk-shear gradients at W2 above the threshold, $\partial S_{b}^{2} / \partial t>2 \times 10^{-11} \mathrm{~s}^{-3}$, used to define shear spikes in section $3 \mathrm{c}$.

Faroe Bank Channel overflow plume (Darelius et al. 2013, their Figs. 4a,d).

\section{c. Current oscillations, tides, and shear at W2}

Near the bottom, the Filchner overflow plume flows westward $\left(257^{\circ}\right)$ with a mean speed of $0.27 \mathrm{~m} \mathrm{~s}^{-1}$. Above the plume (385 mab), a mean current of $0.11 \mathrm{~m} \mathrm{~s}^{-1}$ is directed northwest $\left(320^{\circ}\right)$. Rotary current spectra for the upper layer and lower layer are calculated using halfoverlapping 42-day (1024 hourly data points) Hanning windows. Both layers are strongly influenced by diurnal tides (Fig. 7). In addition, we find a peak in energy for periods of 3-4 days, which is consistent with previous observations in the area (Darelius et al. 2009; Jensen et al. 2013). These oscillations are suggested to be TVWs (Jensen et al. 2013; Marques et al. 2014).

At the diurnal frequency, the clockwise (CW) components (black and dark orange in Fig. 7) are most pronounced, while the counterclockwise (CCW) components (gray and light orange) dominate for frequencies corresponding to periods of 3-4 days. While the diurnal-band signal is approximately deterministic, the lower-frequency TVWs can be excited at random times, as a result of disturbances from wind or the overflow 
dynamics. The frequency at which the TVWs are excited will change with stratification and forcing conditions, resulting in oscillations in a wider frequency band. The broad peak around the 3-4-day period in the frequency spectra is thus a result of random excitation of wave packets in a band of frequencies. Here, we focus on these 24- and 72-h oscillations, which explain approximately $10 \%$ and $25 \%$ of the total variance, respectively.

Tidal currents in the upper layer are comparable to the total current. Tidal analysis is conducted using harmonic analysis (Pawlowicz et al. 2002) over 30-day windows, successively stepped forward by 1 day. A typical tidal current is calculated as the sum of the predicted currents for the $\mathrm{K}_{1}, \mathrm{O}_{1}, \mathrm{M}_{2}$, and $\mathrm{S}_{2}$ constituents. Time-averaged typical tidal current speed is $0.03 \mathrm{~m} \mathrm{~s}^{-1}$ at $386 \mathrm{mab}$ and $0.04 \mathrm{~m} \mathrm{~s}^{-1}$ at $25 \mathrm{mab}$. At $386 \mathrm{mab}$, the mean total current speed is similar to the tidal speed, whereas, the observed current speed near the bottom is one order of magnitude higher $\left(0.27 \mathrm{~m} \mathrm{~s}^{-1}\right)$. The $\mathrm{K}_{1}$ tidal ellipses from two depth bins ( 25 and 384 mab) are presented in Fig. 8a, together with typical tidal current and 15-day low-passed current speed anomalies (time average is removed from each; Fig. 8b). The tidal current anomalies are similar at both levels. The tidal currents vary seasonally, with stronger currents during summer and autumn. For a detailed description of the diurnal tides and the seasonal variability in the southeastern Weddell Sea, see, for example, Semper and Darelius (2017).

We decompose the time series of current velocity into the $\mathrm{CW}$ - and $\mathrm{CCW}$-rotating components with periods of 24 and $72 \mathrm{~h}$, using complex demodulation over 7-daylong segments, each moved by $1 \mathrm{~h}$ (Emery and Thomson 2001). The analysis results in time-variable amplitude and phase for the 72-h oscillation (TVW band) and captures the excitation of this oscillation at random times. The exact frequency of a particular TVW packet can vary in a broader frequency band (e.g., with periods of 3-4 days; section 3c). Based on the Rayleigh criterion, the relatively short window length (7 days) cannot resolve the TVWs close in frequency. Bursts of waves with changing phase and/or small changes in frequency will thus be captured, but smoothed as a 72-h oscillation in the analysis. In the following, we denote the sense of rotation with $\mathrm{CW}$ or $\mathrm{CCW}$ followed by a subscript indicating the period in hours, for example, $\mathrm{CW}_{24}$ is a clockwise rotation with a period of $24 \mathrm{~h}$.

The bulk shear $S_{b}$ is dominated by the variability in the bottom current, with a mean bulk-shear direction toward $253^{\circ}$. Although a seasonal variation is present in the diurnal tidal currents (Fig. 8), we do not see a similar feature in the bulk shear (full time series not shown). In a seasonally stratified temperate shelf sea

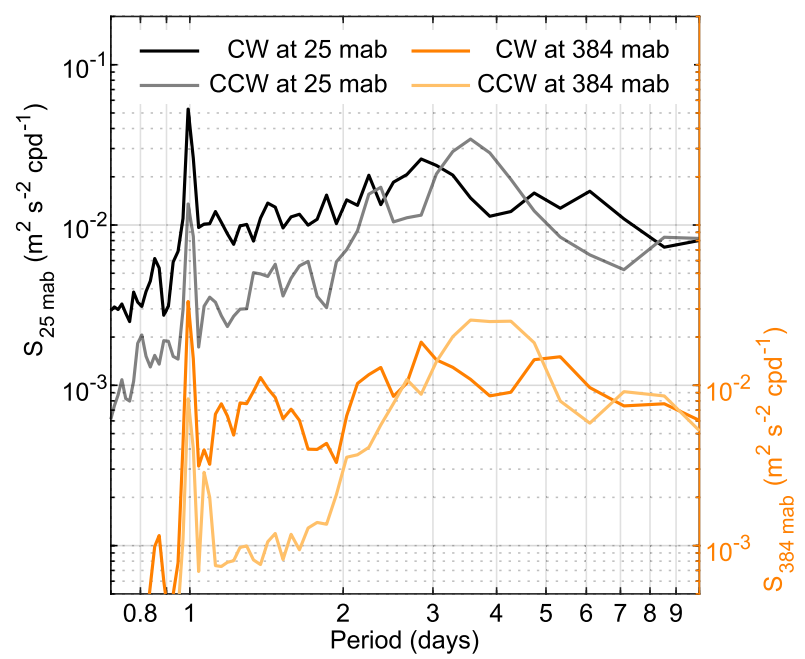

FIG. 7. Rotary spectra for current velocity at the lower an upper layer at W2. The black and gray lines indicate the $\mathrm{CW}$ and CCW components at $25 \mathrm{mab}$, while the dark and light orange lines indicate the $\mathrm{CW}$ and $\mathrm{CCW}$ components at $384 \mathrm{mab}$. The spectra from 384 mab are offset vertically by a factor of 10 , with true power spectral densities indicated on the vertical axis to the right.

with approximately two-layer structure, Burchard and Rippeth (2009) explained episodic shear events using a model based on the bulk-shear vector forced by the wind (inertial shear) and damped by bottom friction. Alignment of the bulk-shear vectors with tidal bed stress led to shear spikes. In a system with well-defined average layer velocities and thickness, the layer-averaged momentum equation including the friction (stress) terms is recast as an equation for the bulk shear. Taking the dot product of the bulk-shear equation with the bulk-shear vector, we obtain the dynamical equation for bulk shear squared, which allows interpretation of the shear-spiking mechanism by alignment. This leads to a term, proportional to the dot product of bulk shear and interfacial stress vectors, where their relative alignment leads to generation or destruction of shear variance. We adopt this method to analyze the variability in bulk shear, using bulk shear squared $S_{b}^{2}$ as the main parameter. Events with $S_{b}^{2}$ elevated above the background values occur in pulses. We define a shear-spike event based on a threshold of the $S_{b}^{2}$ growth rate $\left(\partial S_{b}^{2} / \partial t>2 \times 10^{-11} \mathrm{~s}^{-3}\right)$, similar to, for example, Burchard and Rippeth (2009) and Brannigan et al. (2013).

Large bulk shear and fluctuations in plume thickness are observed between 20 March and 15 April 2010 (Fig. 9). During this period we identify 21 spike events associated with a thickening of the Filchner overflow plume (marked by red circles in Fig. 9). During the shear-spike events, two counterrotating oscillations, the upper-layer $\mathrm{CW}_{24}$ and the 


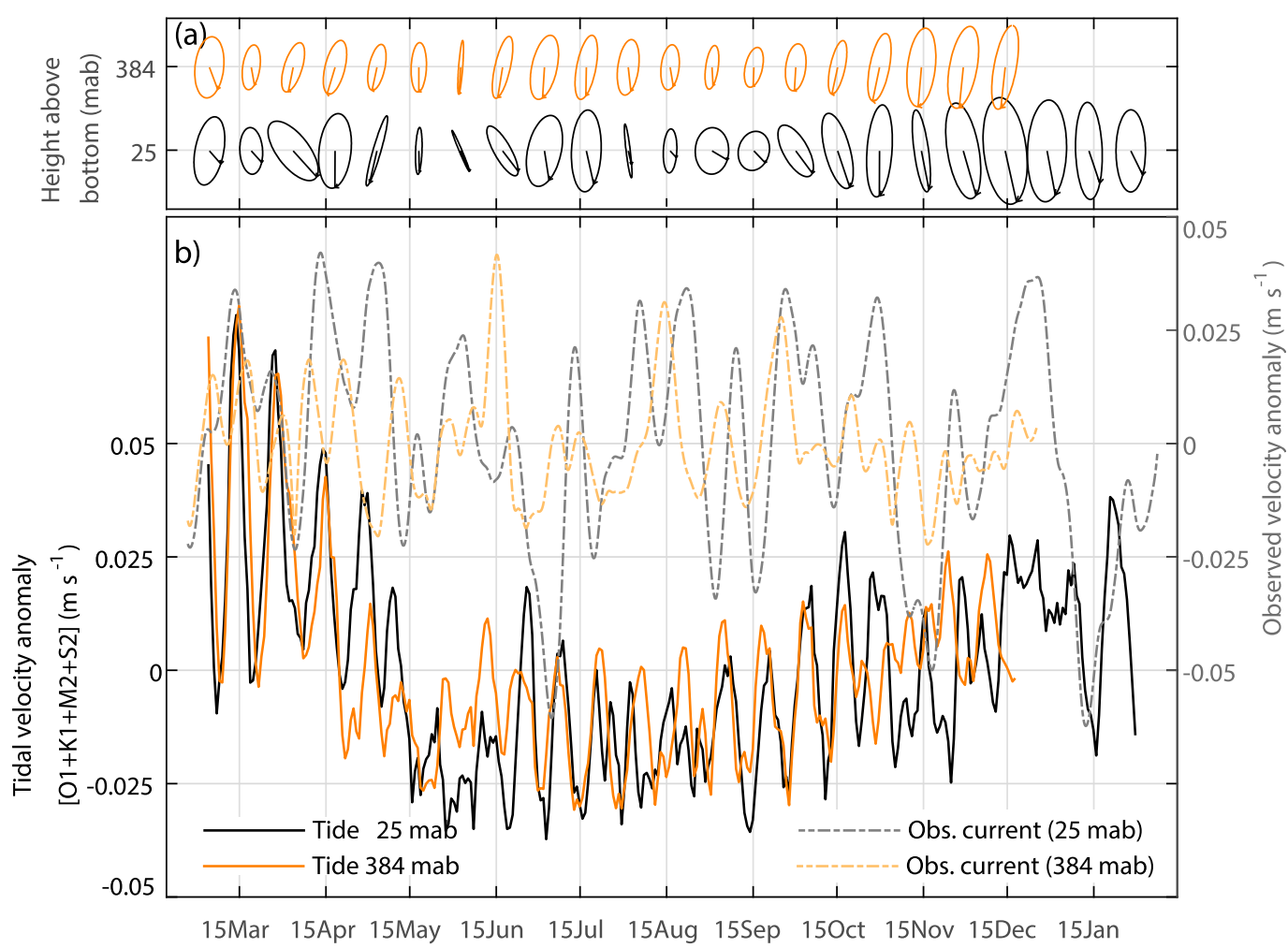

FIG. 8. Time series of (a) $\mathrm{K}_{1}$ tidal ellipses at 25 (black) and $384 \mathrm{mab}$ (orange), and (b) tidal current speed (sum of $\mathrm{K}_{1}, \mathrm{O}_{1}, \mathrm{M}_{2}$, and $\mathrm{S}_{2}$ ) anomalies (left vertical axis), and daily low-passed current speed anomalies (right vertical axis) at 25 and $384 \mathrm{mab}$.

bulk-shear $\mathrm{CCW}_{72}$, tend to align. Alignment occurs in 16 of the 21 shear-spike events shown in Fig. 9d. Alignment of $\mathrm{CW}_{24}$ and $\mathrm{CCW}_{72}$ is expected every $36 \mathrm{~h}$ and is consistent with the observed time interval between two events. Throughout the full record, we observe 279 shear-spike events, and roughly $70 \%$ of these show such alignment.

\section{Discussion}

Here we discuss mechanisms for variability at different time scales and their implications for the production of AABW. We first discuss the low-frequency variability, and then continue with the short-term variability and possible mechanisms for the 72-h oscillation.

\section{a. Variability on monthly to interannual time scales}

Upstream of the FT, the monthly scale slope current variability is largely wind driven (Graham et al. 2013; Daae et al. 2018). In a recent study, Daae et al. (2018) showed that also the monthly scale variability of the Filchner overflow velocity is related to the along-slope wind stress upstream (upstream region indicated by orange lines in Fig. 1). The correlation between the wind stress and the Filchner overflow velocity varies from year to year, depending on the strength of the along-slope wind forcing. Daae et al. (2018) propose that a branch of the slope current may recirculate over the Filchner sill region during strong wind forcing. Interaction between the wind-driven, recirculating slope current and the Filchner overflow could possibly explain the covariability of the wind stress and the overflow velocity. In 2010, when data from W2 and W3 are available, the correlation between wind stress and overflow velocity at S2 is weak (insignificant above the $90 \%$ confidence). However, there is significant correlation between the upstream wind stress and the along-flow bottom current at W2 $\left(R=0.41^{95}\right)$, suggesting a wind influence on the bottom current along the slope, similar to what is observed in the slope current, upstream of the FT (Graham et al. 2013; Daae et al. 2018).

There is a similar response to the seasonal heaving of the Antarctic slope front thermocline at the Filchner sill (S2) and on the continental slope downstream (W2 and W3) (Semper and Darelius 2017). On monthly scales, a strong variability in both dense-water properties and $T_{d}$ is observed at all moorings. The variability at W2 and W3 is, at least in part, linked to the upstream conditions at S2 (section 3a). The highest correlation is found between density at $176 \mathrm{mab}$ at $\mathrm{S} 2$ and at $25 \mathrm{mab}$ at 

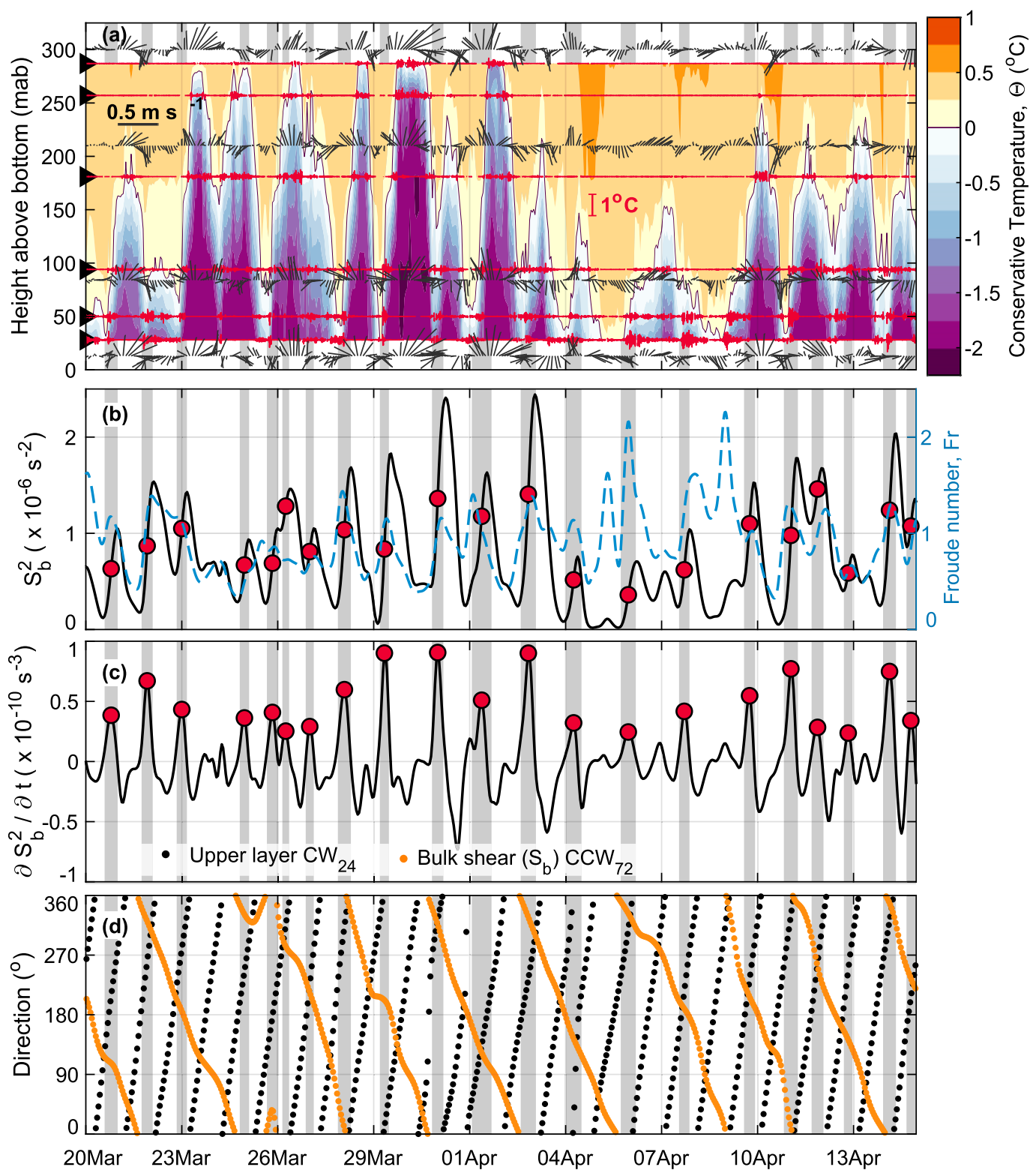

FIG. 9. (a) Time series of $\Theta$ (colors), high-passed $\Theta$ anomalies (thin red lines), and current vector anomalies (black) at W2. (b) Bulk-shear squared $S_{b}^{2}$ between 25 and 388 mab (black) and Froude number (blue). (c) Time derivative of $S_{b}^{2}$. (d) Direction of $\mathrm{CW}_{24}$ in the upper layer (black) and the $\mathrm{CCW}_{72}$ in the bulk shear (orange). Red circles show peaks in $\partial S_{b}^{2} / \partial t$ above a threshold of $2 \times 10^{-11} \mathrm{~s}^{-3}$, and the gray shading indicates the duration (width at half prominence) of each spike event.

W2 $\left(R=0.63^{99}\right)$. In addition, the slope current variability upstream of the FT may also be advected and contribute to the observed variability at $\mathrm{W} 2$ and $\mathrm{W} 3$.

In a model study, Wang et al. (2012) found a seasonal signal in the Filchner shelf water export rate, resulting from onshore propagating density anomalies related to wind-forced isopycnal depression at the coast. We observe such seasonality in neither $T_{d}$ nor the overflow velocity at S2. However, the total ISW transport is not resolved, as our study is based on only one mooring. Additional observations across the overflow plume are needed to assess the seasonality of the plume.

\section{b. Source of subinertial oscillations}

Oscillations with periods of 24 and $72 \mathrm{~h}$ dominate the current variability at W2. The 24-h oscillation is a result of barotropic TVWs excited by the strong diurnal tides (Middleton et al. 1987). The properties of the 72-h 
oscillation are also consistent with TVWs (Jensen et al. 2013). However, the high energy levels at this frequency could also result from eddies advected past the moorings, or from instabilities generated locally within the plume. Laboratory experiments (Lane-Serff and Baines 2000) and idealized numerical model experiments (Wang et al. 2009) suggest that vortex stretching in the Filchner overflow plume would lead to eddies with periods of about 3 days. Other mechanisms known to induce instability are roll waves and baroclinic instability, discussed below.

\section{1) Roll Waves}

The observed thick-plume events resemble a pattern expected from internal roll waves. Roll waves may develop on turbulent flows with large bottom friction and are characterized by shock-like pulses of energetic turbulence (Balmforth and Mandre 2004). High Froude numbers $(\mathrm{Fr}>2)$, which is the necessary criterion for the development of roll waves (Fer et al. 2002; Swaters 2003), occur frequently at W2 (Figs. 5d, 9b), especially in the first part of the records (March-July). However, the time scale of the plume events is subintertial (1-3 days), whereas roll waves are expected to occur at superinertial frequencies. Swaters (2003) reports roll waves with periods around $2 \mathrm{~h}$. The role of bottom friction over the Weddell Sea continental slope is also smaller than the rotational effect. The bottom friction term $C_{D}\left|\mathbf{u}_{b}\right| \mathbf{u}_{b} / H_{p}$ and the Coriolis term $f \mathbf{u}_{b}$, calculated using a drag coefficient of $C_{D}=0.003$ (a typical value for energetic overflows, calculated from microstructure measurements in the Faroe Bank Channel overflow; Fer et al. 2010), with $\mathbf{u}_{b}$ the velocity at $25 \mathrm{mab}, H_{p}$ the height of the $0^{\circ} \mathrm{C}$ isotherm, and $f$ the Coriolis parameter, give an average ratio of Coriolis to friction terms of approximately 19 . While this is a rough estimate, it indicates that the effect of rotation is more important than the effect of bottom friction. We conclude that the thick-plume events are not a result of roll waves.

\section{2) BAROCLINIC INSTABILITY}

Moorings W2 and W3 are located on a steep continental slope, with a slope steepness of 0.03 . Over sloping topography, baroclinic instability on a plume interface can lead to alternating cyclonic and anticyclonic eddies (Tanaka and Akitomo 2001). The sloping topography has both a stabilizing effect, due to the topographic $\beta$ effect, and a destabilizing effect, due to the steepening of the isopycnal surface. Unstable waves occur more frequently on steep slopes, where the destabilizing effect overcomes the stabilizing effect. However, the eddy transport velocity decreases as the slope steepens (Tanaka 2006), and the duration of the development stage reduces.
According to Tanaka (2006), baroclinic instabilities over the Weddell Sea continental slope reach a mature stage after 16 days. We infer a similar time scale using a twolayer linear instability model (Poulin and Swaters 1999; Reszka et al. 2002). The model describes a two-layer coupled system over sloping topography. The upper layer is continuously stratified and is governed by the incompressible and adiabatic fluid equations. The density current in the lower layer is described by the shallowwater equations over a sloping bottom (Poulin and Swaters 1999), where we apply parameters representative of the Weddell Sea slope. No combination of plume thickness, plume width or slope steepness gives periods shorter than 20 days. Furthermore, growing baroclinic instabilities require a substantial vertical phase shift (Spall and Price 1998). Eddies formed from growing baroclinic instabilities of the overflow plume are expected to be more energetic in the dense bottom layer than in the layer above. Coherency spectra and phase are computed at W2 between the 396 mab at increasing vertical separation. Phase change in the vertical (relative to $396 \mathrm{mab}$ ) for the cross-slope velocity component is small $\left[2^{\circ}-6^{\circ}\right.$ $\left.(100 \mathrm{~m})^{-1}\right]$, in the frequency bands of $24 \mathrm{~h}, 35 \mathrm{~h}$, and 3 days with high coherency. Our observations are therefore not suggestive of baroclinic instability. In agreement with former studies, we suggest that TVWs or vortex stretching are the more likely causes of the 72-h oscillation (Darelius et al. 2009; Jensen et al. 2013; Marques et al. 2014).

\section{c. Alignment of oscillations with 24- and 72-h periods}

Shear spiking may trigger the development of shear instabilities and contribute to diapycnal mixing. Shear spiking is shown to be a significant source of turbulent kinetic energy production across the seasonal thermocline in shallow stratified shelf seas (Rippeth et al. 2009; Burchard and Rippeth 2009), near the sea bed in Arctic shelf seas (Lenn et al. 2011), and at the base of the oceanic mixed layer (Brannigan et al. 2013). At W2, we observe that the upper-layer $\mathrm{CW}_{24}$ and the plume-layer $\mathrm{CCW}_{72}$ are typically aligned during shear-spike events. Note that the counterrotating oscillations need not be phase locked. While the diurnal-band oscillations are relatively deterministic as a result of dominant tidal forcing, the excitation times of the lower-frequency TVWs are random. Provided that there are two counterrotating vectors, they will eventually align.

The shear spikes coincide with an increase in plume thickness, and they are associated with enhanced temperature variance and high Froude numbers, which indicate strong mixing and entrainment of ambient water (Cenedese and Adduce 2008; Turner 1986). Unfortunately, we cannot quantify the contribution of 
shear spiking to the total mixing over the continental slope. Further studies are needed, using mooring arrays and microstructure measurements, to resolve the shearspiking mechanism, the mixing associated with the shear spiking, and the along-slope variation in the Filchner plume characteristics.

The thick-plume events following the shear spikes contribute substantially to the dense water transport density $T_{d}$ along the continental slope. By partitioning the contribution of the transport density into a lower part (up to a threshold thickness) and an upper part associated with the thick-plume events, we find that thick-plume events with thickness above 75,100 , and $150 \mathrm{~m}$ contribute with $35 \%, 22 \%$, and $8 \%$ of the total $T_{d}$ at W2, and $20 \%, 10 \%, 2 \%$ of $T_{d}$ at $\mathrm{W} 3$, respectively.

Alignment of the $\mathrm{CW}_{24}$ and the $\mathrm{CCW}_{72}$ oscillations does not explain all the detected shear spikes. In theory, the $\mathrm{CW}_{24}$ and the $\mathrm{CCW}_{72}$ oscillations are aligned every $36 \mathrm{~h}$, if they were phase locked. While this time scale agrees with the observed average time interval between two thick-plume events, the phase locking of the oscillations is not expected, nor required, for the shear-spiking mechanism. However, frequent and regular occurrences of shear spiking, as observed in our dataset, would contribute to a more frequent turbulence generation and mixing. The dynamics and the wavewave interactions are complex and are not accurately resolved in our analysis using 7 -day-long segments. The rotary spectra from W2 also show elevated energy in a broad band centered at the 35 -h period for the $\mathrm{CW}$ component in the upper layer (dark orange line in Fig. 7). The common presence of several low-frequency band oscillations along the Weddell Sea continental slope (Jensen et al. 2013) may interfere with the alignment of $\mathrm{CW}_{24}$ and $\mathrm{CCW}_{72}$, and hence the timing of shear-spike events.

\section{d. Revised transport estimates at the Filchner sill}

F04 estimated a cold shelf-water transport of $1.6 \pm$ $0.5 \mathrm{~Sv}$ over the Filchner sill based on two moorings from 1985 (see map in Fig. 1). Three yearlong records exist from the westernmost mooring site, S2 (1977, 1985, and 1987). The mean overflow velocities are similar in the 1985 and 1987 records, but are stronger in 1977 (Darelius et al. 2014b; Daae et al. 2018). The S2 mooring location was moved roughly $13 \mathrm{~km}$ eastward in 2003 , 2009, and 2010. The new S2 location is between the S2 and S3 sites from 1985 (see map in Fig. 1). Observations from the new S2 location indicate an approximate doubling of the overflow velocity (Darelius et al. 2014b). The difference in overflow velocity could indicate an increase in the ISW transport after 1987; alternatively, it could result from the change in mooring position. In late
1987, three large icebergs grounded on the Berkner Shelf and caused variations in the water mass characteristics and the flow pattern in the FT (Nøst and Østerhus 1998; Grosfeld et al. 2001). If the core of the outflow approached the new S2 location, it could explain the higher velocities observed here. If this were the case, the current measurements by F04 did not capture the high velocities in the core of the ISW flow, and hence underestimated the transport. By estimating the transport of cold water at the new S2 site using the method described in F04, and assigning a width of $65 \mathrm{~km}$ (as they do for their S2), we obtain a transport of $2.2 \mathrm{~Sv}$. This is $0.5 \mathrm{~Sv}$ more than their estimate from the combined S2 and S3 moorings with a total width of $137 \mathrm{~km}$.

The width of the overflow plume is not resolved in 1985 or in 2010. It is therefore not possible to conclude whether the ISW transport has changed during this period. The observed changes in the overflow velocity could reflect either different distances between the moorings and the outflow core or changes in the overflow transport related to interannual or longer term variability. The ISW properties within the FT vary from year to year (Darelius et al. 2014a), but the interannual variability of the ISW volume flux emanating from the Filchner Ice Shelf front is not well documented. The production of ISW depends on atmospheric conditions, and the rate of sea ice formation (Nicholls et al. 2009). Unfortunately, long ISW circulation/recirculation times inside the FRIS cavity (Nicholls and Østerhus 2004) combined with limited observations make it difficult to estimate interannual ISW volume fluxes based on available atmospheric data.

Our method for estimating transport densities $T_{d}$ differs from F04 in the definition of the ISW and the vertical interpolation (see section $2 c$ and F04). Our method gives significantly lower values compared with F04's method. To test if the discrepancy is related to the different ISW thresholds, we recalculate the transport density at S2 in 2010 using the same temperature-based ISW threshold as F04. Transport density $T_{d}$ is $25 \mathrm{~m}^{2} \mathrm{~s}^{-1}$ in both cases, indicating a low sensitivity to the ISW threshold. The discrepancy in $T_{d}$ is therefore more likely to result from the vertical interpolation and extrapolation. While we exclude parts of the water column above the uppermost instrument, and consider the effect of bottom friction, $\mathrm{F} 04$ calculate the transports using three boxes, centered around three instruments, with vertical extrapolation below the bottom instrument and above the upper instrument.

The transport estimates across the continental slope (calculated using our method at W2 and W3) compare well with F04 (F-section). However, keeping in mind the discrepancy in $T_{d}$ estimated from the two methods at S2, we 
cannot conclude whether the Filchner overflow transport density differs significantly between 1998 and 2010.

\section{e. Formation of $A A B W$ in a changing climate}

The production of AABW depends both on the source water masses (HSSW and ISW) and on the entrainment of WDW during the descent of the Filchner plume along the continental slope (Gill 1973; Orsi 1999). AABW has become fresher since the 1980s (Purkey and Johnson 2013). The freshening is most pronounced in the South Pacific Ocean and the south Indian Ocean, where the freshening corresponds to roughly half the recent mass loss of the West Antarctic Ice Sheet. Although the freshening of $\mathrm{AABW}$ from the Atlantic sector is weaker, the freshening of the AABW exported from the Weddell Sea is significant (Jullion et al. 2013). Atmospheric-forced ice shelf collapse, deglaciation, and sea ice changes on the eastern side of the Antarctic Peninsula are suggested to be the main source of AABW freshening (Jullion et al. 2013). Another possible source to freshening is changes in the sea ice production and export over the continental shelf (Haumann et al. 2016). During the last 30 years, the sea ice production over the Weddell Sea continental shelf has substantially reduced, with subsequent reduction in both formation of HSSW and transport of HSSW under the Filchner-Ronne Ice Shelf (K. W. Nicholls et al. 2017, unpublished manuscript). In turn, this leads to a freshening of the Filchner overflow plume and also fresher AABW.

Our study suggests that high shear and mixing across the Filchner overflow plume interface is related to alignment of counterrotating oscillations with periods of 24 and $72 \mathrm{~h}$. This mechanism may be important for the entrainment of WDW and the production of AABW. The sensitivity of this mixing mechanism to the ISW freshening is uncertain. While the 24-h oscillation is related to tides and TVWs, which are independent of the ISW density, the 72-h oscillation is associated with vortex stretching or TVWs from the Filchner overflow plume. The amplitude or frequency of the oscillation can change if the ISW freshens. Given that the ISW freshening is moderate, the 72 -h oscillation can be expected to persist in the future. However, if the Filchner overflow transport weakens, the thickness and pathway of the plume along the continental slope may be altered, which in turn could lead to changes in the mixing mechanisms and production rates of AABW.

\section{Conclusions}

We present observations of hydrography and current from three moorings located along the pathway of the Filchner overflow plume in the southeastern Weddell Sea. The monthly scale plume variability over the upper continental slope is related to upstream conditions at the Filchner sill. A strong variability in plume thickness is observed along the continental slope on shorter time scales (1-3 days). The thickness of the plume on the upper slope varies from less than $25 \mathrm{~m}$ to more than $287 \mathrm{~m}$. Plume events thicker than average contribute substantially to the mean overflow transport density.

Shear spikes are observed as the plume thickens and may contribute to enhanced mixing and entrainment of ambient water masses. The shear spikes are associated with alignment of $\mathrm{CW}$ and $\mathrm{CCW}$ rotating oscillations with periods of 24 and $72 \mathrm{~h}$, respectively. The $\mathrm{CW}_{24}$ is related to diurnal tides and TVWs, while $\mathrm{CCW}_{72}$ could either result from vortex stretching of the dense plume (Lane-Serff and Baines 2000; Darelius et al. 2009; Wang et al. 2009) or from westward-propagating TVWs (Jensen et al. 2013).

Additional independent evidence of turbulence associated with the plume variability is documented by observations of increased temperature variance and high Froude numbers, which promote enhanced mixing. The temperature variance and Froude number both increase at the thickening and decaying stages of thick-plume events. Mixing and entrainment are important for the production of WSBW, which is ultimately transformed into AABW. Direct measurements of ocean microstructure, either using profilers from ships or using sensors on autonomous ocean gliders (Fer et al. 2014; Peterson and Fer 2014) are needed. However, to observe bottomattached thin plumes in deep water is challenging. Provided that the suggested mixing mechanism between ISW and WDW is invariant to a moderate freshening of the ISW, future changes in WSBW properties will depend on processes controlling the formation of dense shelf water over the continental shelf.

Acknowledgments. This work is supported by the Centre for Climate Dynamics at the Bjerknes Centre and by the Norwegian Research council's FRINATEK program through the project WARM (231549) and through the NARE program under the project WEDDELL (211415). For deployment and recovery of moorings, we thank Svein Østerhus and the crew and scientists on RRS Ernest Shackleton (cruise ES052) and RRS James Clark Ross (cruise JR244). Mooring data from W2 and W3 are available at https://doi.org/10.1594/PANGAEA.871146. Mooring data from S2 were provided by Svein Østerhus (Uni Research Climate, and the Bjerknes Centre for Climate Research, Bergen, Norway) and are submitted to the Norwegian Marine Data Centre (NMDC), http://www.nmdc.no. Filtering software was provided by J. M. Lilly and is available at http:// www.jmlilly.net/jmlsoft.html. Comments from two reviewers helped clarify and improve the manuscript. 


\section{REFERENCES}

Andreas, E. L., T. W. Horst, A. A. Grachev, P. O. G. Persson, C. W. Fairall, P. S. Guest, and R. E. Jordan, 2010: Parametrizing turbulent exchange over summer sea ice and the marginal ice zone. Quart. J. Roy. Meteor. Soc., 136, 927-943, https://doi.org/ 10.1002/qj.618.

Balmforth, N. J., and S. Mandre, 2004: Dynamics of roll waves. J. Fluid Mech., 514, 1-33, https://doi.org/10.1017/ S0022112004009930.

Brannigan, L., Y.-D. Lenn, T. P. Rippeth, E. McDonagh, T. K. Chereskin, and J. Sprintall, 2013: Shear at the base of the oceanic mixed layer generated by wind shear alignment. J. Phys. Oceanogr., 43, 1798-1810, https://doi.org/10.1175/ JPO-D-12-0104.1.

Brink, K. H., 1991: Coastal-trapped waves and wind-driven currents over the continental shelf. Annu. Rev. Fluid Mech., 23, 389-412, https://doi.org/10.1146/annurev.fl.23.010191.002133.

Burchard, H., and T. P. Rippeth, 2009: Generation of bulk shear spikes in shallow stratified tidal seas. J. Phys. Oceanogr., 39, 969-985, https://doi.org/10.1175/2008JPO4074.1.

Carmack, E. C., and T. Foster, 1977: Water masses and circulation in the Weddell Sea. Polar Oceans: Proceedings of the SCOR/ SCAR Polar Ocean Conference, M. J. Dunbar, Ed., Arctic Institute of North America, 151-165.

Cenedese, C., and C. Adduce, 2008: Mixing in a density-driven current flowing down a slope in a rotating fluid. J. Fluid Mech. 604, 369-388, https://doi.org/10.1017/S0022112008001237.

Daae, K., I. Fer, and E. P. Abrahamsen, 2009: Mixing on the continental slope of the southern Weddell Sea. J. Geophys. Res., 114, C09018, https://doi.org/10.1029/2008JC005259.

— - E. Darelius, I. Fer, S. Østerhus, and S. Ryan, 2018: Wind stress mediated variability of the Filchner Trough overflow, Weddell Sea. J. Geophys. Res. Oceans, 123, 3186-3203, https:// doi.org/10.1002/2017JC013579.

Darelius, E., and A. K. Wåhlin, 2007: Downward flow of dense water leaning on a submarine ridge. Deep-Sea Res. I, 54, 11731188, https://doi.org/10.1016/j.dsr.2007.04.007.

- L. H. Smedsrud, S. Østerhus, A. Foldvik, and T. Gammelsrød, 2009: Structure and variability of the Filchner overflow plume. Tellus, 61A, 446-464, https://doi.org/10.1111/j.16000870.2009.00391.x.

_ - J. E. Ullgren, and I. Fer, 2013: Observations of barotropic oscillations and their influence on mixing in the Faroe Bank Channel overflow region. J. Phys. Oceanogr., 43, 1525-1532, https://doi.org/10.1175/JPO-D-13-059.1.

_ , K. Makinson, K. Daae, I. Fer, P. R. Holland, and K. W. Nicholls, 2014a: Hydrography and circulation in the Filchner Depression, Weddell Sea, Antarctica. J. Geophys. Res. Oceans, 119, 5797-5814, https://doi.org/10.1002/2014JC010225.

— , K. O. Strand, S. Østerhus, T. Gammelsrød, M. Årthun, and I. Fer, 2014b: On the seasonal signal of the Filchner Overflow, Weddell Sea, Antarctica. J. Phys. Oceanogr., 44, 1230-1243, https://doi.org/10.1175/JPO-D-13-0180.1.

Dee, D. P., and Coauthors, 2011: The ERA-Interim reanalysis: Configuration and performance of the data assimilation system. Quart. J. Roy. Meteor. Soc., 137, 553-597, https://doi.org/ 10.1002/qj.828.

Emery, W., and R. Thomson, 2001: Data Analysis Methods in Physical Oceanography. 2nd ed. Elsevier Science, 654 pp.

Fahrbach, E., and S. el Naggar, 2001: The expeditions ANTARKTIS XVI/ 1-2 of the Research Vessel POLARSTERN in 1998/1999. Ber. Polar Meeresforsch., 380, 1-177.
Fer, I., U. Lemmin, and S. Thorpe, 2002: Winter cascading of cold water in Lake Geneva.J. Geophys. Res., 107, 3060, https://doi.org/ 10.1029/2001JC000828.

- G. Voet, K. S. Seim, B. Rudels, and K. Latarius, 2010: Intense mixing of the Faroe Bank Channel overflow. Geophys. Res. Lett., 37, L02604, https://doi.org/10.1029/ 2009GL041924.

A. K. Peterson, and J. E. Ullgren, 2014: Microstructure measurements from an underwater glider in the turbulent Faroe Bank Channel overflow. J. Atmos. Oceanic Technol., 31, 1128-1150, https://doi.org/10.1175/JTECH-D-13-00221.1.

- E. Darelius, and K. Daae, 2016: Observations of energetic turbulence on the Weddell Sea continental slope. Geophys. Res. Lett., 43, 760-766, https://doi.org/10.1002/2015GL067349.

Foldvik, A., and T. Gammelsrød, 1988: Notes on Southern Ocean hydrography, sea-ice and bottom water formation. Palaeogeogr. Palaeoclimatol. Palaeoecol., 67, 3-17, https://doi.org/ 10.1016/0031-0182(88)90119-8.

— J. Middleton, and T. Foster, 1990: The tides of the southern Weddell Sea. Deep-Sea Res., 37, 1345-1362, https://doi.org/ 10.1016/0198-0149(90)90047-Y.

- and Coauthors, 2004: Ice shelf water overflow and bottom water formation in the southern Weddell Sea. J. Geophys. Res., 109, C02015, https://doi.org/10.1029/2003JC002008.

Foster, T., and E. C. Carmack, 1976: Temperature and salinity structure in the Weddell Sea. J. Phys. Oceanogr., 6, 36-44, https://doi.org/ 10.1175/1520-0485(1976)006<0036:TASSIT >2.0.CO;2.

Gammelsrød, T., and Coauthors, 1994: Distribution of water masses on the continental shelf in the southern Weddell Sea. The Polar Oceans and Their Role in Shaping the Global Environment, Geophys. Monogr., Vol. 84, Amer. Geophys. Union, 158-176.

Gill, A., 1973: Circulation and bottom water production in the Weddell Sea. Deep-Sea Res. Oceanogr. Abstr., 20, 111-140, https://doi.org/10.1016/0011-7471(73)90048-X.

Graham, J. A., K. J. Heywood, C. P. Chavanne, and P. R. Holland, 2013: Seasonal variability of water masses and transport on the Antarctic continental shelf and slope in the southeastern Weddell Sea. J. Geophys. Res. Oceans, 118, 2201-2214, https:// doi.org/10.1002/jgrc.20174.

Grosfeld, K., M. Schröder, E. Fahrbach, R. Gerdes, and A. Mackensen, 2001: How iceberg calving and grounding change the hydrography in the Filchner Ice Shelf-Ocean System. J. Geophys. Res., 106, 9039-9055, https://doi.org/10.1029/2000JC000601.

Haumann, F. A., N. Gruber, M. Münnich, I. Frenger, and S. Kern, 2016: Sea-ice transport driving Southern Ocean salinity and its recent trends. Nature, 537, 89-92, https://doi.org/10.1038/ nature19101.

Heywood, K. J., R. A. Locarnini, R. D. Frew, P. F. Dennis, and B. A. King, 1998: Transport and water masses of the Antarctic Slope Front System in the eastern Weddell Sea. Ocean, Ice, and Atmosphere: Interaction at the Antarctic Continental Margin, S. S. Jacobs and R. F. Weiss, Eds., Antarctic Research Series, Vol. 75, Amer. Geophys. Union, 203-214.

IOC/SCOR/IAPSO, 2010: The International Thermodynamic Equation of Seawater-2010: Calculation and use of thermodynamic properties. Intergovernmental Oceanographic Commission, Manuals and Guides 56, 220 pp., http://www.teos-10.org/ pubs/TEOS-10_Manual.pdf.

Jacobs, S., 2004: Bottom water production and its links with the thermohaline circulation. Antarct. Sci., 16, 427-437, https:// doi.org/10.1017/S095410200400224X.

Jensen, M. F., I. Fer, and E. Darelius, 2013: Low frequency variability on the continental slope of the southern Weddell Sea. 
J. Geophys. Res. Oceans, 118, 4256-4272, https://doi.org/ 10.1002/jgrc.20309.

Jullion, L., A. C. Naveira Garabato, M. P. Meredith, P. R. Holland, P. Courtois, and B. A. King, 2013: Decadal freshening of the Antarctic Bottom Water exported from the Weddell Sea. J. Climate, 26, 8111-8125, https://doi.org/10.1175/JCLI-D-12-00765.1.

Lane-Serff, G., and P. Baines, 2000: Eddy formation by overflows in stratified water. J. Phys. Oceanogr., 30, 327-337, https://doi.org/ 10.1175/1520-0485(2000)030<0327:EFBOIS > 2.0.CO;2.

Lenn, Y.-D., T. P. Rippeth, C. P. Old, S. Bacon, I. Polyakov, V. Ivanov, and J. Hölemann, 2011: Intermittent intense turbulent mixing under ice in the Laptev Sea continental shelf. J. Phys. Oceanogr., 41, 531-547, https://doi.org/10.1175/ 2010JPO4425.1.

Marques, G. M., L. Padman, S. R. Springer, S. L. Howard, and T. M. Özgökmen, 2014: Topographic vorticity waves forced by Antarctic dense shelf water outflows. Geophys. Res. Lett., 41, 1247-1254, https://doi.org/10.1002/2013GL059153.

Middleton, J., T. Foster, and A. Foldvik, 1987: Diurnal shelf waves in the southern Weddell Sea. J. Phys. Oceanogr., 17, 784-791, https://doi.org/10.1175/1520-0485(1987)017<0784: DSWITS $>2.0 . \mathrm{CO} ; 2$.

Mysak, L., 1980: Recent advances in shelf wave dynamics. Rev. Geophys., 18, 211-241, https://doi.org/10.1029/RG018i001p00211.

Nicholls, K. W., and S. Østerhus, 2004: Interannual variability and ventilation timescales in the ocean cavity beneath FilchnerRonne Ice Shelf, Antarctica. J. Geophys. Res., 109, C04014, https://doi.org/10.1029/2003JC002149.

,,-- K. Makinson, T. Gammelsrød, and E. Fahrbach, 2009: Ice-ocean processes over the continental shelf of the southern Weddell Sea, Antarctica: A review. Rev. Geophys., 47, RG3003, https://doi.org/10.1029/2007RG000250.

Nøst, O. A., and S. Østerhus, 1998: Impact of grounded icebergs on the hydrographic conditions near the Filchner Ice Shelf. Antarct. Res. Ser., 75, 267-284, https://doi.org/10.1029/AR075p0267.

Ohshima, K. I., and Coauthors, 2013: Antarctic Bottom Water production by intense sea-ice formation in the Cape Darnley polynya. Nat. Geosci., 6, 235-240, https://doi.org/10.1038/ngeo1738.

Orsi, A. H., 1999: Circulation, mixing, and production of Antarctic Bottom Water. Prog. Oceanogr., 43, 55-109, https://doi.org/ 10.1016/S0079-6611(99)00004-X.

Pawlowicz, R., B. Beardsley, and S. Lentz, 2002: Classical tidal harmonic analysis including error estimates in MATLAB using T_TIDE. Comput. Geosci., 28, 929-937, https://doi.org/10.1016/ S0098-3004(02)00013-4.

Peterson, A. K., and I. Fer, 2014: Dissipation measurements using temperature microstructure from an underwater glider. Methods Oceanogr., 10, 44-69, https://doi.org/10.1016/ j.mio.2014.05.002.

Poulin, F. J., and G. E. Swaters, 1999: Sub-inertial dynamics of density-driven flows in a continuously stratified fluid on a sloping bottom. II. Isolated eddies and radiating cold domes. Proc. Roy. Soc. London, 455A, 2305-2329, https://doi.org/ 10.1098/rspa.1999.0405.
Purkey, S. G., and G. C. Johnson, 2013: Antarctic Bottom Water warming and freshening: Contributions to sea level rise, ocean freshwater budgets, and global heat gain. J. Climate, 26, 61056122, https://doi.org/10.1175/JCLI-D-12-00834.1.

Reszka, M., G. E. Swaters, and B. Sutherland, 2002: Instability of abyssal currents in a continuously stratified ocean with bottom topography. J. Phys. Oceanogr., 32, 3528-3550, https://doi.org/ 10.1175/1520-0485(2002)032<3528:IOACIA $>2.0 . C O ; 2$.

Rhines, P., 1970: Edge-. bottom-, and Rossby waves in a rotating and stratified fluid. Geophys. Fluid Dyn., 1, 273-302, https:// doi.org/10.1080/03091927009365776.

Rippeth, T. P., P. Wiles, M. R. Palmer, J. Sharples, and J. Tweddle, 2009: The diapcynal nutrient flux and shear-induced diapycnal mixing in the seasonally stratified western Irish Sea. Cont. Shelf Res., 29, 1580-1587, https://doi.org/10.1016/j.csr.2009.04.009.

Sciremammano, F., 1979: Suggestion for the presentation of correlations and their significance levels. J. Phys. Oceanogr., 9, 1273-1276, https://doi.org/10.1175/1520-0485(1979)009<1273: ASFTPO $>2.0 . \mathrm{CO} ; 2$.

Semper, S., and E. Darelius, 2017: Seasonal resonance of diurnal continental shelf waves in the southern Weddell Sea. Ocean Sci., 13, 77-93, https://doi.org/10.5194/os-13-77-2017.

Smith, P., 1976: Baroclinic instability in the Denmark Strait overflow. J. Phys. Oceanogr., 6, 355-371, https://doi.org/10.1175/ 1520-0485(1976)006<0355:BIITDS >2.0.CO;2.

Spall, M., and J. Price, 1998: Mesoscale variability in Denmark Strait: The PV outflow hypothesis. J. Phys. Oceanogr., 28, 1598-1623, https://doi.org/10.1175/1520-0485(1998)028<1598: MVIDST $>2.0 . \mathrm{CO} ; 2$.

Swaters, G. E., 2003: Baroclinic characteristics of frictionally destabilized abyssal overflows. J. Fluid Mech., 489, 349-379, https://doi.org/10.1017/S0022112003005135.

Tanaka, K., 2006: Effects of the Earth's rotation and bottom slope on a density current descending a sloping bottom. J. Geophys. Res., 111, C11018, https://doi.org/10.1029/2006JC003677.

— , and K. Akitomo, 2001: Baroclinic instability of density current along a sloping bottom and the associated transport process. J. Geophys. Res., 106, 2621-2638, https://doi.org/ 10.1029/2000JC000214.

Turner, J. S., 1986: Turbulent entrainment: The development of the entrainment assumption, and its application to geophysical flows. J. Fluid Mech., 173, 431-471, https://doi.org/10.1017/ S0022112086001222.

Voet, G., and D. Quadfasel, 2010: Entrainment in the Denmark Strait overflow plume by meso-scale eddies. Ocean Sci., 6, 301-310, https://doi.org/10.5194/os-6-301-2010.

Wang, Q., S. Danilov, and J. Schröter, 2009: Bottom water formation in the southern Weddell Sea and the influence of submarine ridges: Idealized numerical simulations. Ocean Modell., 28, 5059, https://doi.org/10.1016/j.ocemod.2008.08.003.

- E. Fahrbach, J. Schröter, and T. Jung, 2012: On the impact of wind forcing on the seasonal variability of Weddell Sea Bottom Water transport. Geophys. Res. Lett., 39, L06603, https://doi.org/10.1029/2012GL051198. 